$$
\text { مجلة جامعة الملك عبدالعزيز: الآداب والعلوم الانسانية، م29ع3 ص ص: 337- } 356 \text { (2021م) }
$$

DOI:10.4197/Art.29-3.12

\title{
عناية السنة النبوية الشريفة بسلامة الإنسان الأحاديث الواردة في النوم أنموذجًا
}

\author{
د. دمعود بن محمد القحطاني

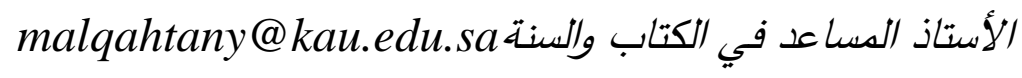 \\ قسم الثربعة والدراسات الإسلامية - كلية الآداب والعلوم الإنسانية \\ جامعة الملك عبد العزيز - جدة
}

مستخلص. الحمد لله رب العالمين، وصلى الله وسلم على نبينا محمد وآله وصحبه أجمعين، يتكون هذا البحث من مبحثين تظهر عناية السنة النبوية الثريفة بسلامة الإنسان قبل النوم وعنده وبعده.

ومن النتائج: النهي عن ترك النار مشتعلة عند النوم واستحباب غسل اليدين قبل النوم وبعده واستحباب النوم مبكرا والاستيقاظ باكراً.

التوصيات: دراسة الأحاديث النبوية الثريفة التي تتعلق بسلامة الإنسان في كافة الجوانب ونشرها في مختلف وسائل

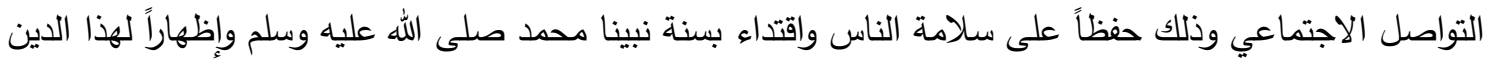
الحق.

مما يحتاجه الخلق في أمر دينهم ودنياهم إلا بينه الله

$$
\text { أحسن بيان. }
$$

أهمية البحث: إن من عظمة هذا الدين وكماله أنه

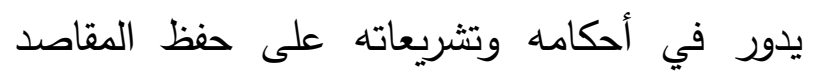
الخمسة الكبرى، وهي الدين والنفس والنسل والمال

\section{المقدمة}

الحمد لله رب العالمين، وصلى الله وسلم على نبينا

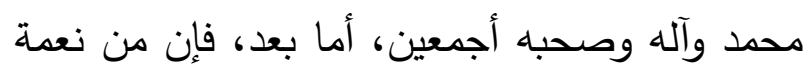

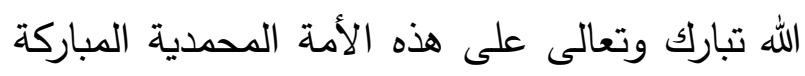

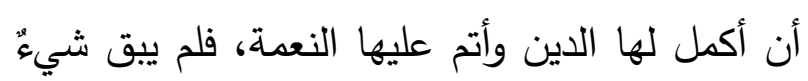


والعقل، ومردّها إلى حفظ الأديان والأبدان، فحفظ خطة البحث: قسمت البحث إلى مقدمة ومبحثين النفس يأتي ثانيا بعد حفظ الدين، بل قدمه بعضهم وخاتمة على النحو التالي:

المبحث الأول: عناية السنة النبوية الشربفة بسلامة الإنسان قبل النوم ويحتوي على خمسة مطالب: المطلب الأول: الأمر بإطفاء النار قبل النوم. المطلب الثاني: الأمر بكف الصبيان وإغلاق الأبواب وتغطية الآنية وإيكاء الأسقية. المطلب الثالث: الأمر بنفض الفراش قبل النوم. المطلب الرابع: الاستياك قبل النوم وبعده. المطلب الخامس: الأمر بغسل اليدين قبل النوم. المبحث الثاني: عناية السنة النبوية الثريفة بسلامة الإنسان عند النوم وبعده وبحتوي على خمسة

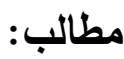
المطلب الأول: النهي عن النوم على سَطْح غير • مُحَجَّر المطلب الثاني: النهي عن النوم على البطن. المطلب الثالث: النوم على الثق الأيمن. المطلب الرابع: النوم مبكراً والاستيقاظ باكراً. المطلب الخامس: غسل اليدين بعد الاستيقاظ من

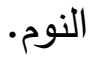

الاراسات السابقة: كتب العلماء في عناية السنة النبوية الشريفة بسلامة الإنسان تبعًا لا استقلالاً كما جاء في كتب الجوامع والصحاح والسنن والمسانيد والمصنفات والآداب وكذلك مؤلفات الإعجاز العلمي
على حفظ الدين (1).

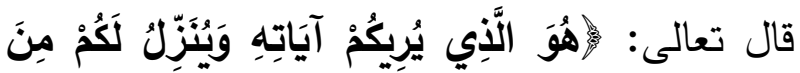

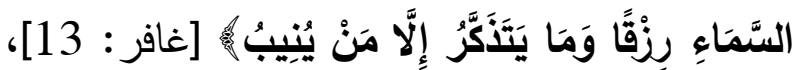
وهذه آية عظيمة جمع الله فيها بين حفظ الأديان بإنزال الآيات، وحفظ الأبدان بإنزال الأرزاق، قال الفخر الرازي: "واعلم أن أهمَّ المهمات رعايةٌ مصالح الأديان، ومصالح الأبدان، فهو سبحانه وتعالى راعى مصالح أديان العباد بإظهار البينات والآيات، وراعى مصالح أبدانهم بإنزال الرزق من السماء، فموقع الآيات من الأديان كموقع الأرزاق من الأبدان، فالآيات لحياة الأديان، والأرزاق لحياة الأبدان، وعند حصولهما يحصل الإنعام على أقوى الاعتبارات وأكمل

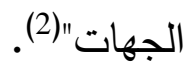
وعناية الشريعة بصحة الأبدان وسلامتها ظاهرة كذلك في تقاريق الأحكام والتشريعات في العبادات والمعاملات والحدود والجنايات وما يتصل بها، ولن تخطئ عينالك وأنت تطوّف بدلائل الوحي الإشاراتِ الكثيرةَ في هذا الباب، وقد وقع اختياري على أحاديث النوم وما فيها من التوجيهات والإشارات النبوية المتصلة بما نحن فيه، وعنونت للبحث "عناية السنة النبوية الشريفة بسلامة الإنسان، الأحاديث الواردة في

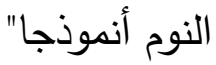

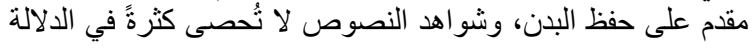


وعن أبي موسى الأشعري عَبِّة قال: احْتَرَقَ بَيْتُ عَلَى

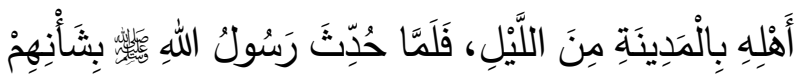

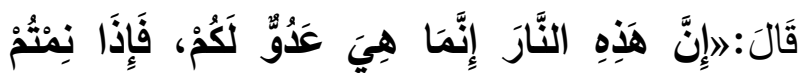

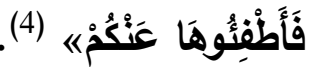

وعن جابر بن عبد الله رضي الله عنهما قال: قَالَ

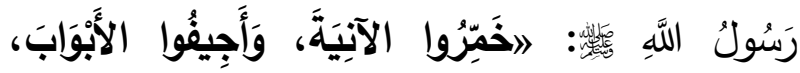

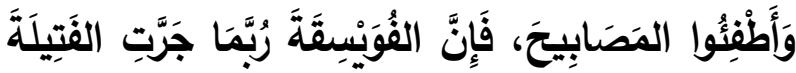

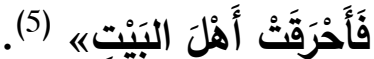
وحديث جابر رضي الله عنه هذا له طرق ستأتي الإثارة إليها بإذن الله في المبحث الثالث. وهذه الأحاديث فيها بيان خطورة ترك النار مشتعلة عند النوم، فإن النار لا يُؤمن جانبها، ولا سبيل في لي لاني كثير من الأحيان إلى إخماد لهيبها، والتجرِبة والواقع

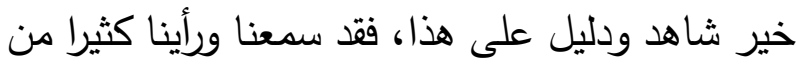
البيوت احترقت على أصحابها في الليل لهذا السبب،

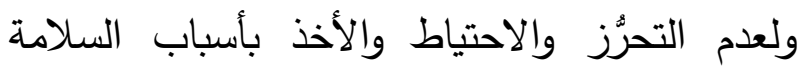

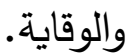

قال ابن الجوزي: "هذا تأديب يتضمن التحذير مما يمكن وقوعه، فإنه ربما هبت الريح بثوب أو غيره إلى لئ النار، وربما وقع على النار شيء فاشتعل واشتعل باه البيت، وربما جرت الفأرة الفتيلة فأحرقت، ثم إنما يراد الضوء للمنتبه، فإيقاد النار بعد النوم من غير حاجة تفريط" (6). وقال ابن الملقن: "وفي هذِه الأحاديث الإبانة عن أن
في الكتاب والسنة، ووققت على رسالة علمية بعنوان (منهج الإسلام في سلامة الإنسان ) للباحث عبد الرحمن الحسيني ، وقد وقف على مباحث من منهج

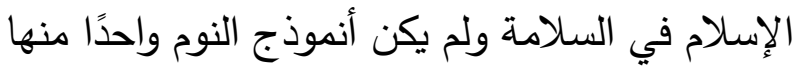
، وكذلك رسالة بعنوان (نحو مفهوم شرعي للسلامة ) للباحث عبد الله الطريقي وهي دراسة نظرية لمفهوم السلامة لمفهومها وأنواعها وأهميتها. منهج البحث: اعتمد البحث على المنهج العلمي الاستقرائي في تتبع الأحاديث التي وردت في سلامة الإنسان في النوم ومن ثم تخريج هذه الأحاديث من الصحيحين وإن لم توجد فيهما أو في أحدهما يتت التخريج من الكتب الأربعة ومن ثم من باقي مصنفات الحديث ثم بيان حكمها وأقوال العلماء فيها. وأخيراً نسأل الله عزوجل العون والتوفيق للجميع للالتزام بسنة رسول الله صلى الله عليه وسلم حفظاً للإنسان وطلباً للأجر والمثوبة. وأخر دعوانا أن الحمد لله رب العالمين عناية السنة النبوية الثريفة بسلامة الإنسان الأحاديث الواردة في النوم أنموذجًا المبحث الأول: عناية السنة النبوية الثريفة بسلامة الإنسان قبل النوم ويحتوي على خمسة مطالب: المطلب الأول: الأمر بإطفاء النار قبل النوم:

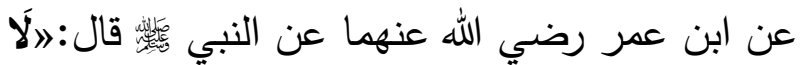

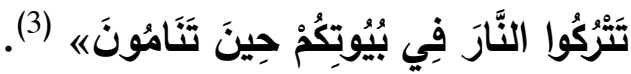


كما هو الغالب فالظاهر أنه لا بأس بها لانتفاء العلة"(9).

وقال ابن دقيق العيد: "وإذا أُمر بإطفاء النار مطلقا، فهو أعم من نار السراج، فالأمر المعلَّق بإطفاء المصابيح لأجل العلة المذكورة؛ وهي جر الفتيلة، إذا لإناه

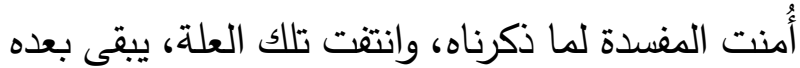
الأمر بإطفاء النار متتاولا للمصباح المتوقد المأمونِ معه جرٌ الفتيلة، وقد تتطرق بذلك مفسدة أخرى غيرُ جر الفتيلة؛ كسقوط شيء من السراج على بعض

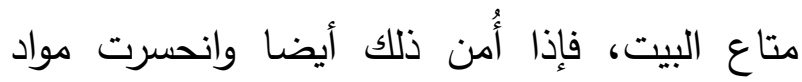
الفساد، فلا يبعد العمل بمقتضى زوال العلة، وهو زوال

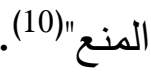
تنبيه: النوم الوارد في الأحاديث يشمل نوم الليل والنهار، وإن كان حصول الضرر في الليل أكثر وأظهر ، لكن وقوعه في النهار مدكن، بل حصل كثيرا كما هو معلوم ومشاهد. المطلب الثاني: الأمر بكَفِّ الصبيان وإغلاق الأبواب وتغطية الآنية وإيكاء الأسقية: عن جابر بن عبد الله رضي الله عنهما قال : قَالَ رَسُولُ اللَّهِ

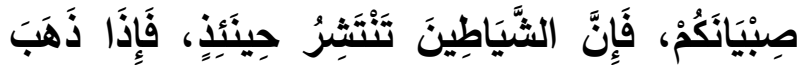

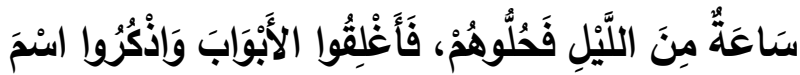

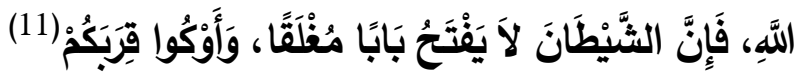

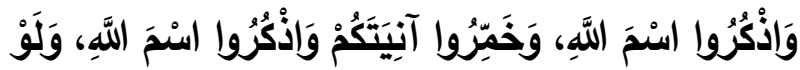

(10) شر ح الإلمام بأحاديث الأحكام (590/2-591).

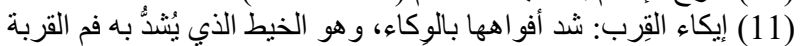
و السقاء.
من الحق على من أراد المبيت في بيت ليس فيه غيره، وفيه نار أو مصباح أن لا يبيت حتى يطفئه أو أو يُحرزه بما يأمن به إحراقَه وضُره، وكذلك إن كان فيه جماعة لإن فالحق عليهم إذا أرادوا النوم ألا ينام آخرهم حتى يفعل

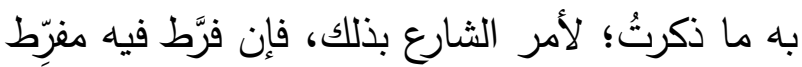
فلحقه ضُر في نفس أو مال كان لوصيته لأمته

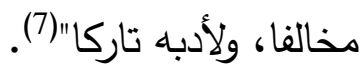
والأمر والنهي في هذه الأحاديث للندب والإرشاد على النى ما ذهب إليه جماهير أهل العلم، وخالف في ذلك فهده الظاهرية فقالوا بالوجوب (8). والنار في الأحاديث عامة يدخل فيها نار المُرُج والمصابيح والثُّموع والكوانين والمَواقد والمدافئ التي لني يستعملها الناس اليوم بسائر أنواعها؛ وذلك أن العلة المستفادة من ظواهر الأحاديث هي خشية حصول شيء من الفساد بسبب بقاء النار مشتعلة، ومن ذلك جرُ الفويسقة الفتيلةَ، وليست العلة منحصرةً في ذلك لك

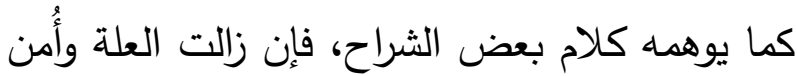
الفساد كما في بعض أنواع الإنارة الحديثة الكهربائية

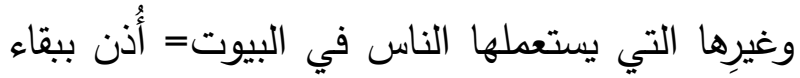
النار مشتعلة؛ لزوال العلة حينئذ.

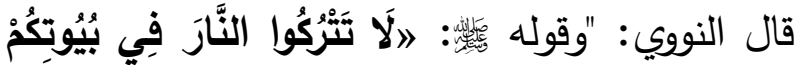
حِينَ تَنَامُونَ، : هذا عام تدخل فيه نار السراج وغيرها،

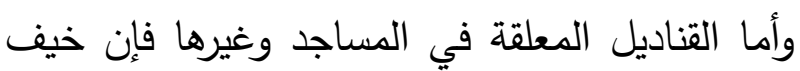
حريق بسببها دخلت في الأمر بالإطفاء، وإن أمن ذلك

(7) التوضيح لثر ح الجامع الصحيح (154/29-155). (8) انظر : فتح الباري (86/11)، وعمدة القاري (187/27/22) (152). (9) شرح النووي على مسلم (187/13). 
الأحاديث: "وقد تضمنت جملة هذه الأحاديث أن الله تعالى قد أطلع نبيه

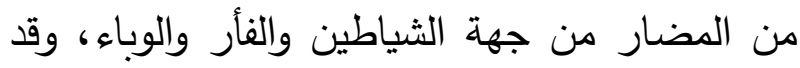

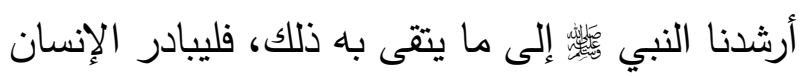

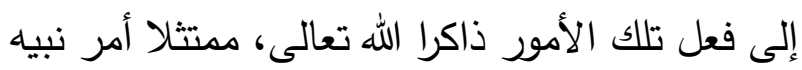

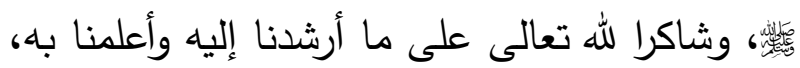
ولنبيه من شيء من ذلك ضرر بحول الله وقوته، وبركة امتثال أوامره ئس أمتّه، فلقد بلغ ونصح" (17). وقال النووي في شرحه حديثَ جابر هِّئه: "هذا الحديث فيه جمل من أنواع الخير والأدب الجامعة لمصائ لنائح

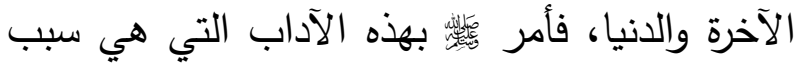
للسلامة من إيذاء الثيطان، وجعل الله عز وجل هذه الأسباب أسبابا للسلامة من ايذائه، فلا يقدر على لهى

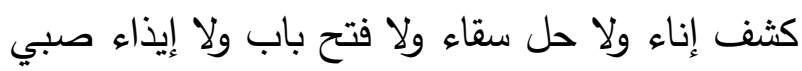
وغيره إذا وُجدت هذه الأسباب" (18).

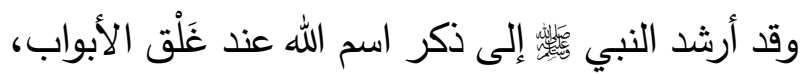

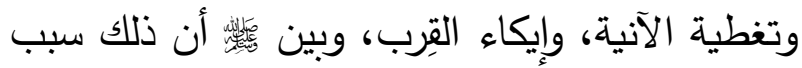
في حفظها من الثيطان الذي لا ينفك عن السعي في

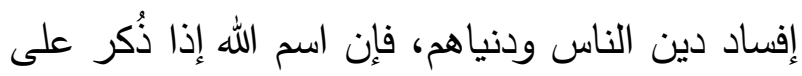
شيء كان ذلك سببا في حفظه وحلول البركة فيه كما هو معلوم، وشدد

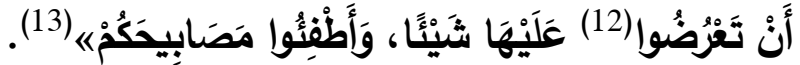

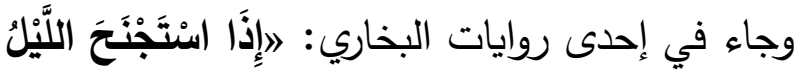

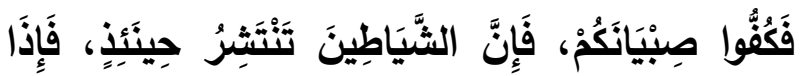

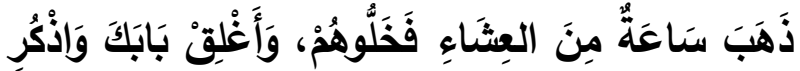

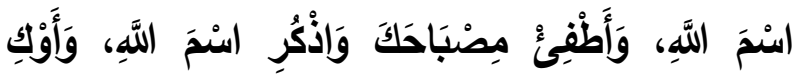

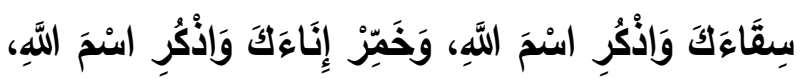

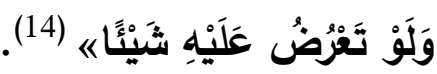

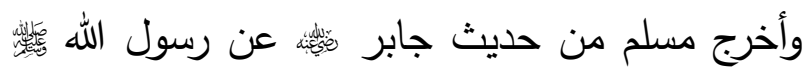

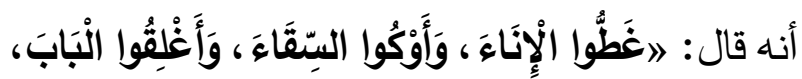

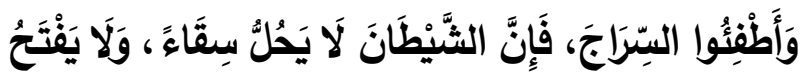

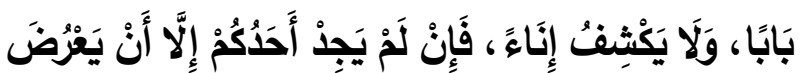

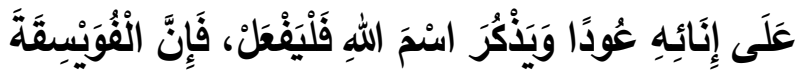

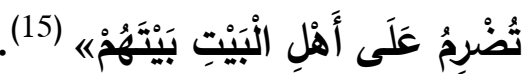

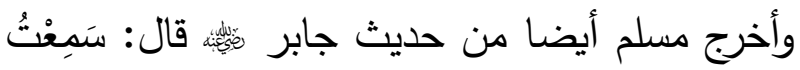
رَسُولَ اللهِ

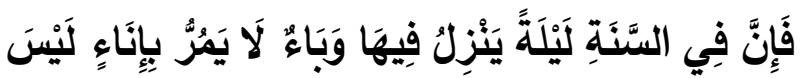

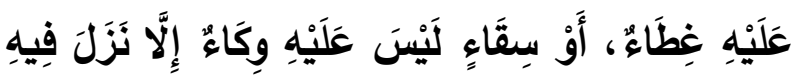
مِنْ ذَلَكِكَ الْوَبَاءِ هذه جملة من الأحاديث والتوجيهات النبوية العظيمة في هذا الباب، وكثير منها يغفُل عنه الناس ويُهملونه ولا يبالُونه، وأنت ترى حرصه وحثه وتخويفه وتئه

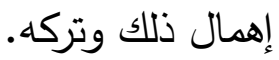
قال أبو العباس القرطبي في شرحه على مجموع هذه

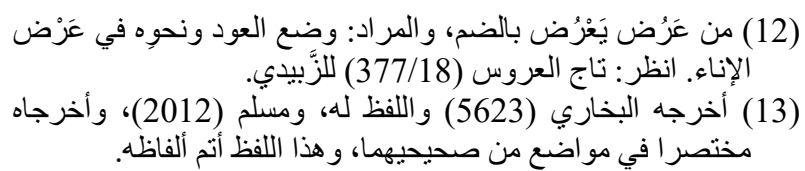
.(3280) (14) 


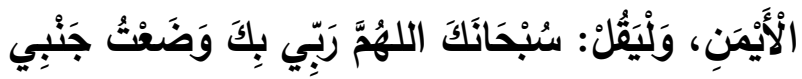

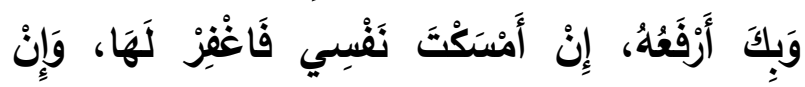

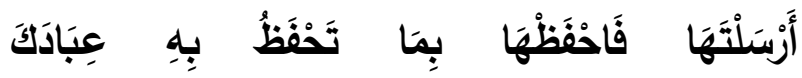
الصَّالِِِينَه (22).

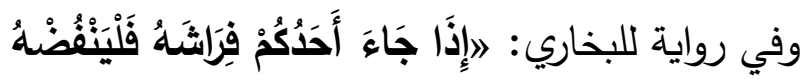

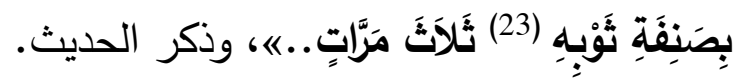
هذا الحديث فيه توجيه نبوي عظيم بتعاهد المرء فرارثه

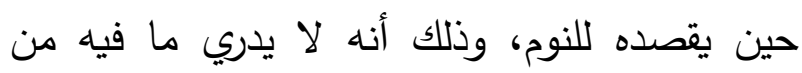

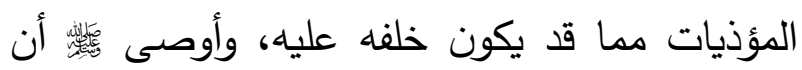
يكون ذلك بطرف الإزار لحكمة تأتي الإثارة إليها،

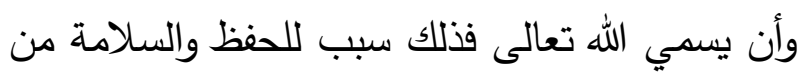
الأذى، وأن يفعل ذلك ثلاث مرات، والوتر له اعتبار في الثرع كما هو معلوم. قال النووي: "ومعناه أنه يستحب أن ينُض فرل فراشه قبل

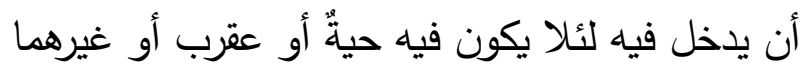
من المؤذيات، ولينفض ويدُه مستورة بطرَف إزاره؛ لئلا يحصل في يده مكروه إن كان هناك" (24). وقال أبو العباس القرطبي: "هذا الديث يتضمن العناك العان الإرشاد إلى مصلحتين:

إحداهما: معلومة ظاهرة، وهي: أن الإنسان إذا قام عن فراشه لا يدري ما دبَّ عليه بعده من الحيوانات ذوات الدات إنات السموم، فينبغي له إذا أراد أن ينام عليه أن يتفقده

(107/2)

(22) أخرجه البخاري (6320)، ومسلم (2714) و اللفظ له، كلاهما من طريق سعيد بن أبي سعيدٍ المقبري عن أبيه به.

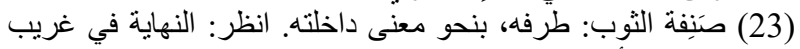
الحديث و الأثر (56/3).

(24) شرح النووي على مسلم (36/17-37).
وعلل ذلك بالوباء الذي ينزل ليلة في السنة، ونحن

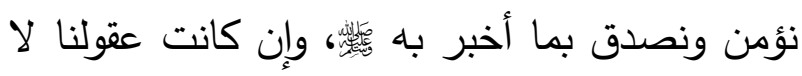

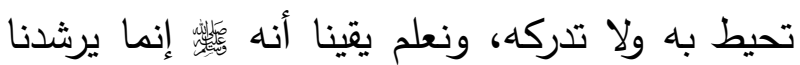
ويلنا على ما فيه صلاحنا في دينتا ودنيانا.

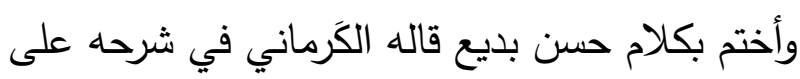

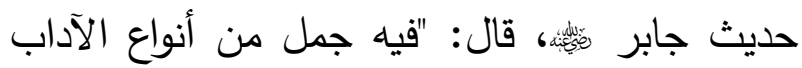

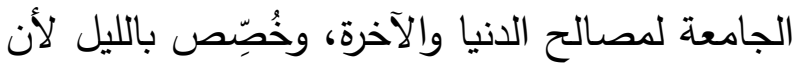
غسق الليل وقتُ ظهور الأشرار، وقد ضَبط أحوالهم لألهان

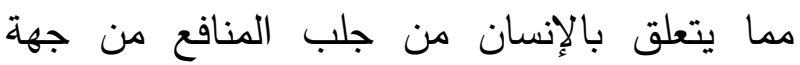

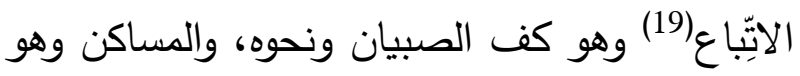
غلق الأبواب، والدشارب وهو إيكاء القرب، والمطاعم وهو تخمير الأواني، ومن دفع المضار وهو الئاء اليرب، والطفاء

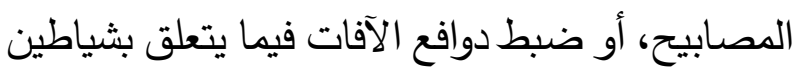
الجن فبكف الصبيان، وما يتعلق بشياطين الإنس فبالإغلاق، وما بالآفة السماوية فبإيكاء القربة وتخمير الآنية، وما بالآفة الأرضية فبالإطفاء، وهذا كله على الإنى سبيل التمثيل والباقي يقاس عليه" (20). المطلب الثالث: الأمر بنفض الفراش قبل النواش النوم:

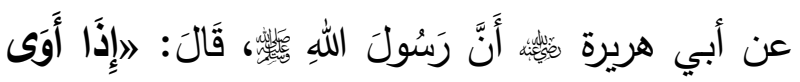

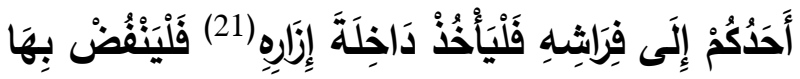

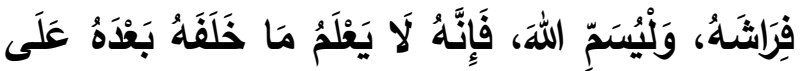

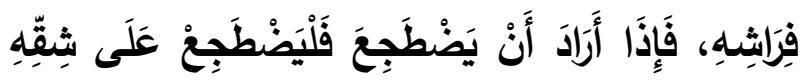

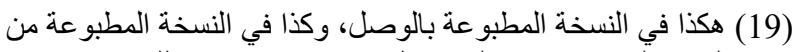

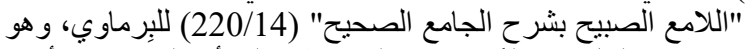

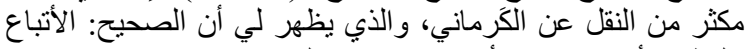

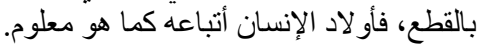

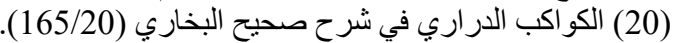

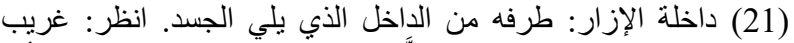
الحديث (113/2) للقاسم بن سلَّام، و النهائة في غريب الحديث الجيث و الأثر
} 
جسده، وذلك داخلة إزارة، ويرد ما أمسكه بيمينه على ما يلي جسده من الإزار، فإذا صار إلى فراشه فحل إزاره، فإنما يحل بيمينه خارجة الإزار ، ويبقى الداخلة

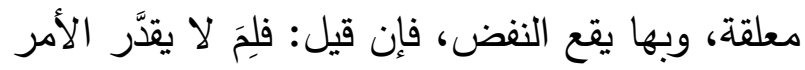

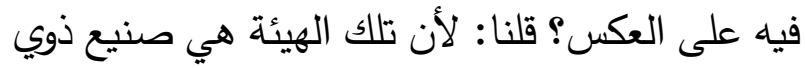
الآداب في عَقد الإزار، ومناط الفائدة فيه أن المؤتزر

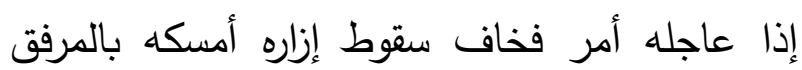
الأيسر ، ودفع عن نفسه بيمينه"(29). بقي أن يشار إلى أن النفض بطرف لعنه الإزار ليس متعينا،

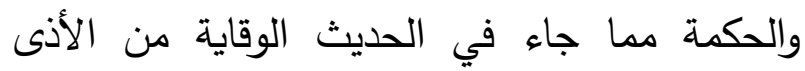
والضرر، فمتى تيسر هذا بأي شيء حصل المقصود إن شاء الله، والله أعلى وأعلم.

المبحث الثامن: الاستياك قبل النوم وبعده:

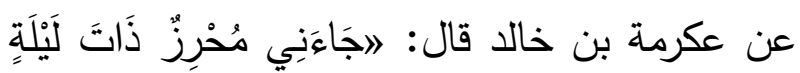

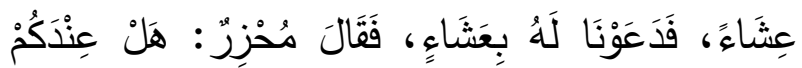

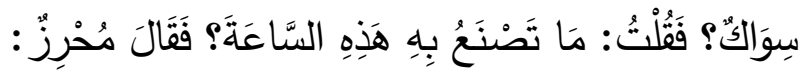
إِنَّ رَسُولَ اللهِ

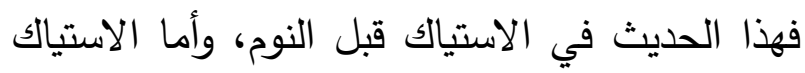
بعده فهو الأشهر والأكثر ، وفيه جملة من الأخبار عنده :

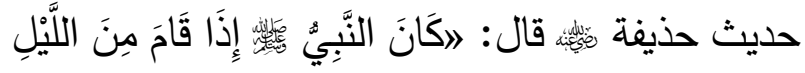

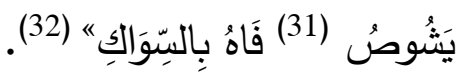
وحديث ابن عمر رضي الله عنهما ضأَنَّ رَسُولَ اللهِ

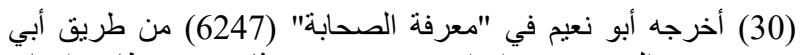

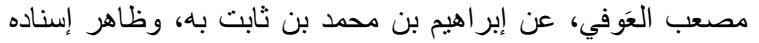

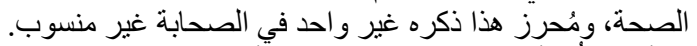

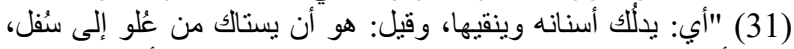

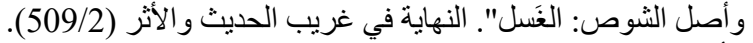
(32) أخرجه البخاري (245)، ومسلم (255).
ويمسحء؛ لإمكان أن يكون فيه شيء يخفى من رطوبة أو غيرها، فهذه مصلحة ظاهرة. وأما اختصاص هذا النفض بداخلة الإزار فمصلحة لم هُه

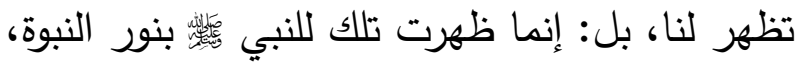

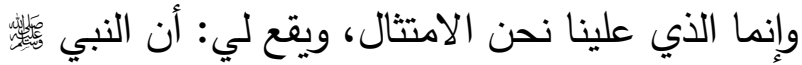
علم فيه خاصية طبية تنفع من ضرر بعض

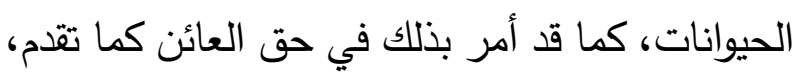
والله تعالى أعلم، ويدل على ذلك ما زاده الترمذي في

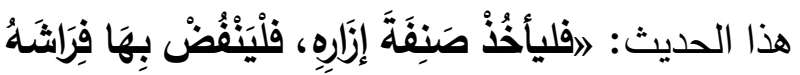

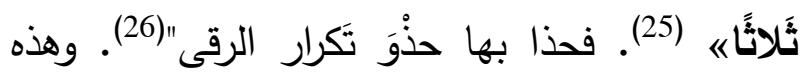
الحكمة والمصلحة التي أشار إلى خفائها وعدم ظهورها أشار إليها بعض أهل العلم. قال ابن حجر : "وأشار الداودي فيما نقله بن التين إلى الى

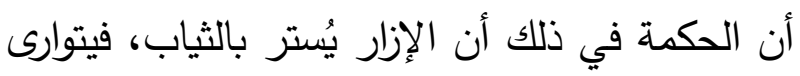
بما يناله من الوسخ، فلو نال ذلك بكُمِه صار غير لََْن (27) الثُب، والله يحب إذا عمل العبد عملا أن يحسنه" (28.

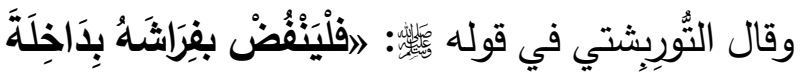

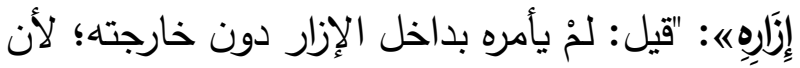
ذلك أبلغ وأجدى، وإنما ذلك على جهة الخبر عن فعل باهل الفاعل؛ لأن المؤتزر إذا ائززر يأخذ أحد طرفي إزاره

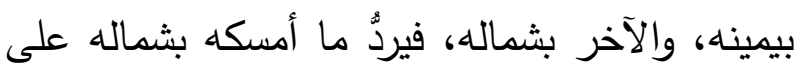

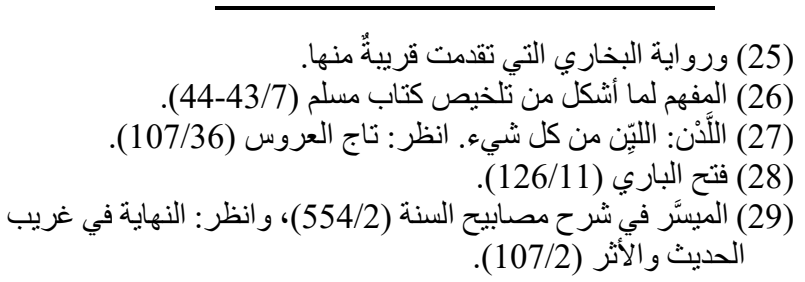

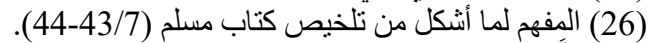

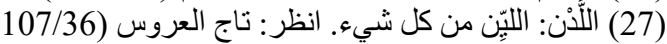
(28) فتح الباري (126/11). الحديث والاثثر (107/2). 
الطعام، ويسمِّل مجاري الكلام، وينِّبط للقراءة والذكر والصلاة، ويطرد النوم، ويرضي الرب، ويعجب

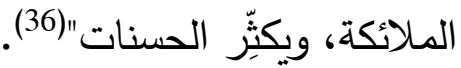
والسواك مستحب في كل حال، وهو في مواضع

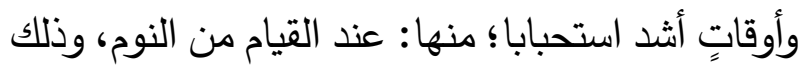
أن "النوم مقتضٍ لتغير الفم، والسواك هو آلة التتظيف للفم، فيسن عند مقتضى التغير "(37). وكلام الشراح غالبه يدور حول هذا المعنى المذكور،

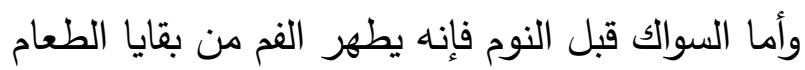
العالقة في الأسنان، والتي يضر بقاؤها ويسارع في تغير رائحة الفم وتسوس الأسنان.

المطلب الخامس: الأمر بغسل اليدين قبل النوم:

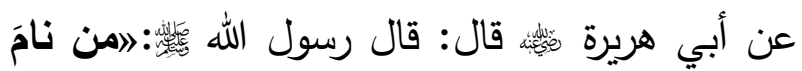

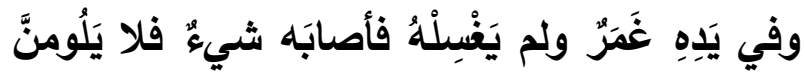
إلا نفسَهه" (38).

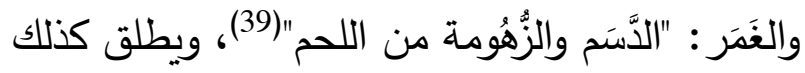
على ما بقيت رائحته في اليد من الدسم واللحم (40). وهذا الحديث فيه حث وندب أكيد على غسل اليدين قبل النوم من الدسم ورائحة اللحم، وذلك أن الذي ينام

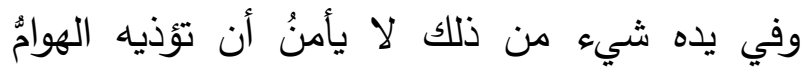

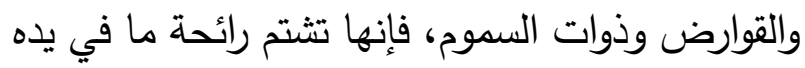

شرح الإلمام بأحاديث الأحكام (3852) (130/3) له أيضا.

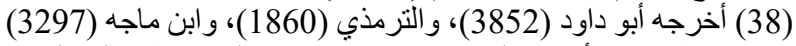

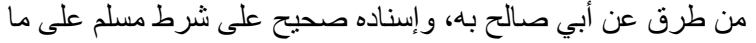

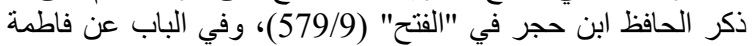

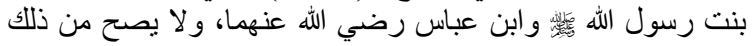
(39) النهاية في غريب الحديث و الأثر (385/3). لإين (381/2). (40) انظر: جمهرة اللغة (781/2) لابن دُريد، والهِّحاح (773/2)

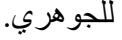

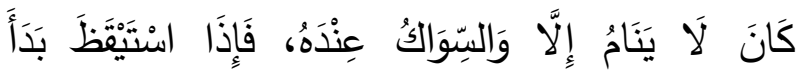
بِالسِيَوَالكِ « (33). وحديث ابن عباس رضي الله عنهما رأَنَّهُ بَاتَّ عِنْدَ

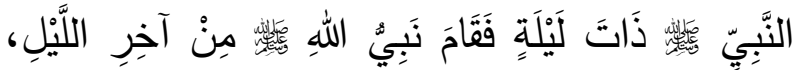

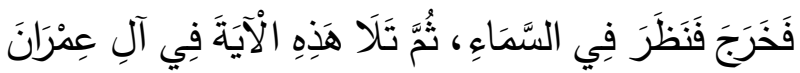

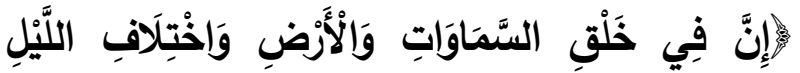

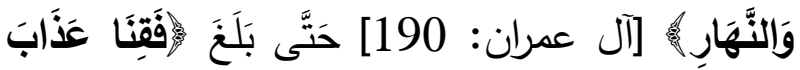

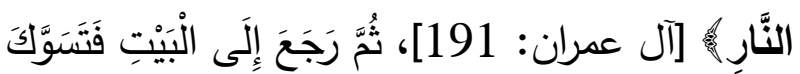

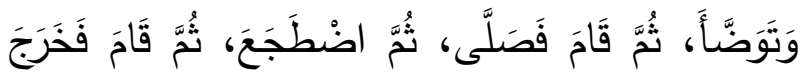

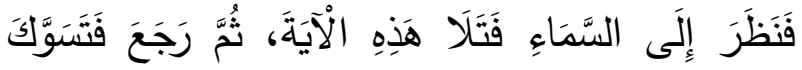

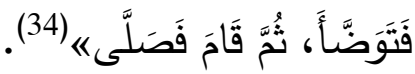

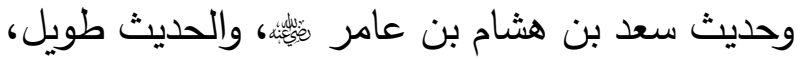

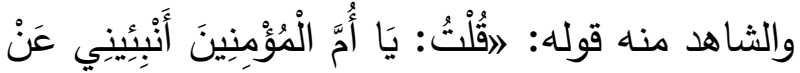

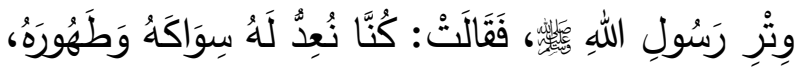

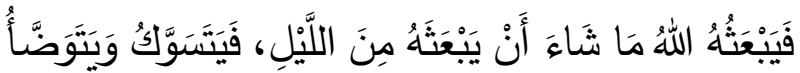
وَيُصَلِّيه". وذكر الحديث (35).

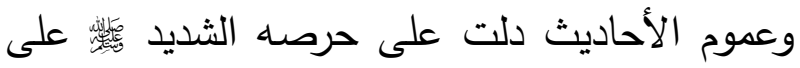
السواكَ وحتٍّ أمته عليه لما فيه من المنافع العظيمة الدينية والدنيوية، ومن ذلك: أنه "يطِّبِ الفم، ويشدُ

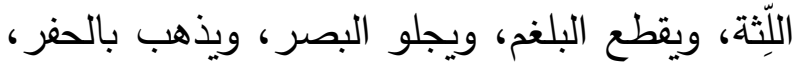

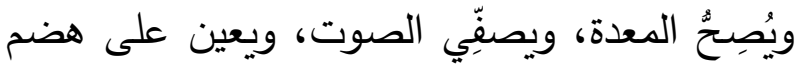

(33) أخرجه أحمد (5979) من طريق محمد بن مسلم بن مِهران بها،

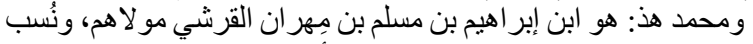

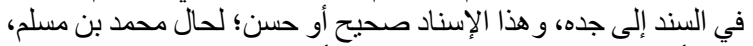

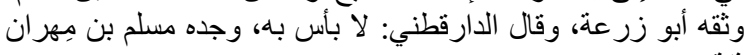

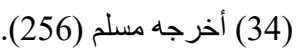

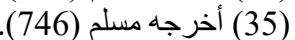

(36) زاد المعاد (35) (376/4).

(37) إحكام الأحكام شرح عمدة الأحكام (108/1) لابن دقيق العيد، و انظر : 
جاء في جملة دن كتب الشروح (45) والآداب أن من بات وفي يده غمَر يُخشى عليه من البرص والثيطان،

$$
\text { واستدلوا على ذلك بحديثين: }
$$

الأول: حديث أبي سعيد الخدري نِّئئه عن النبي

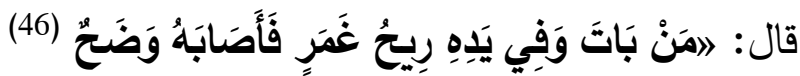
فَلَا يَلُومَنَّ إِلَّا نَفْسَهُهُ

والثاني: حديث أبي هريرة نِئئه: قال: قال رسول الله

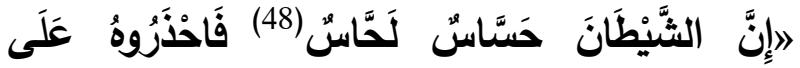

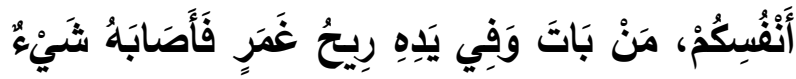

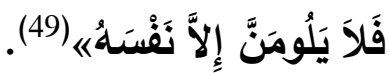

والحديثان ضعيفان لا تقوم بهما حجة.

المبحث الثاني: عناية السنة النبوية الثريفة بسلامة

الإنسان عند النوم وبعده وبحتوي على خمسة مطالب:

المطلب الأول: النهي عن النوم على سَطْح غير مُحَجَّر:

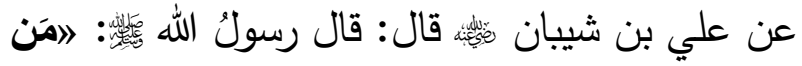

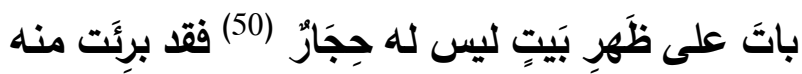

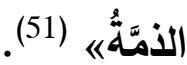

الأئمة و النقاد على تو هينه.

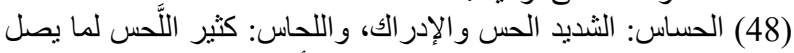

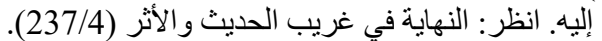

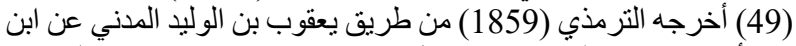

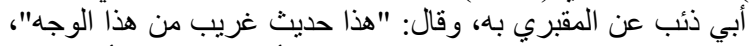

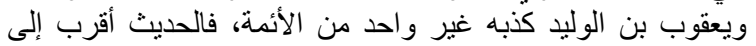

الوضع.

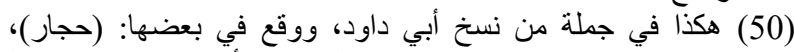

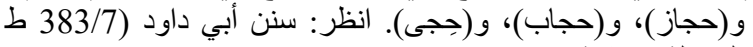
الرسالة- حاثشية).

(51) أخرجه أبو داود (5041) و اللفظله، و البيهقي في الآداب (ص: 276)
قال الطيبي: "وقوله: (فأصابه شيء): أي إيذاء من الهوامّ، وذلك لأن الهوامَ وذوات السموم ربما تقصده في المنام لرائحة الطعام في يده فتوذذيه"(41). وأعرف من أكل سمكا في الليل ونام ولم يغسل يديه كما ينبغي فقصده قارض يتثمَّم يديه، ولطَف الله به

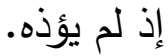

والأَّلى في الغسل هنا أن يكون بالماء والصابون أو ما يقوم مقامه من الكُنظّفاتات مما يزيل أثر الرائحة، قال ابن رسلان في قوله فئل: (ولم يغله): "وإطلاقه

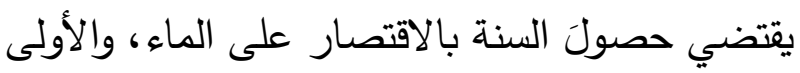
غسل اليد منه بالأشنان أو الصابون ولأنسار على الماه، والاولي معناهما"(42). وحديث أبي هريرة الذي تقدم يؤيده ما جاء في الصحيحين من حديث ابن عباس رضي الله عنهما أَنَّ

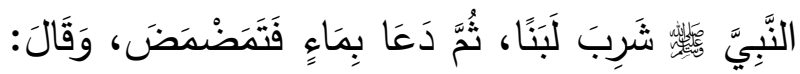
(إنَّ لَهُ دَسَمًَا هذا الحديث يستفاد منه "استحباب تنظيف الفم من

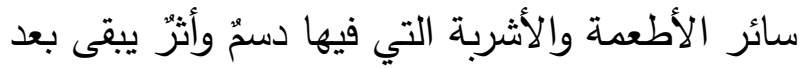
أكلها، وكذا تتظيفُ اليدين ونحوهما من أطرافه"(44).

(41) الكاثف عن حقائق السنن (شرح مشكاة المصابيح) (2857/9).

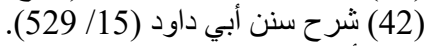
(43) أخرجه البخاري (421) (211)، ومسلم (15) (358).

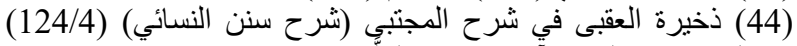
لمحمد بن علي بن آدم الإثيوبي الولوئي الوبي.

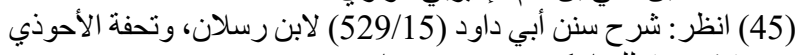

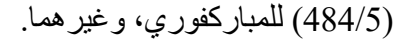

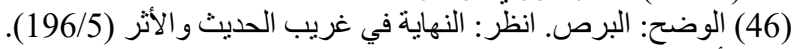

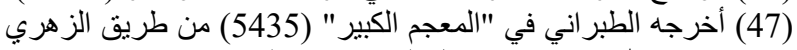

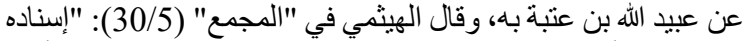
حسن"، و الأظهر ضعفه؛ لحال عبد الله بن صالح كاتب الليث، فأكثرُ 


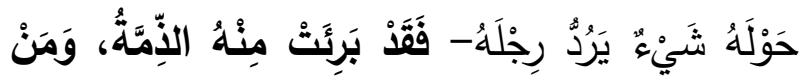

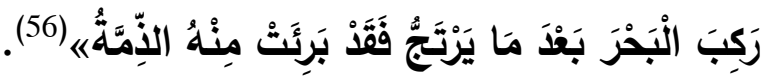

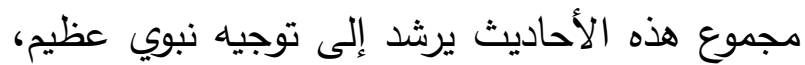

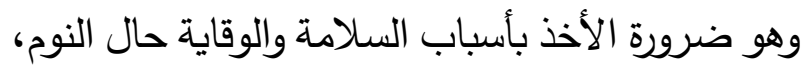
فلا ينبغي أن يعرِّض المريه نفسه لما فيه هلاكه وعطبُّه، ومن ذلك أن ينام فوق سنطح ليس لله سور ولا ليا

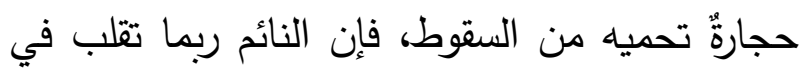
نومه، أو استيقظ فقام يمشي وهو غافل، أو هجم عليه

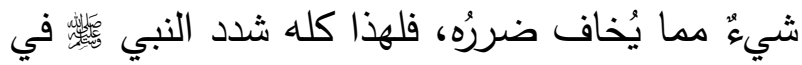
ذذلك، ونهى عن النوم على هذه الحال، وتوعد من فعل ذلك بأنه "تصدى للهلاك، وأزال العصمة عن نفسه، وصار كالمهر الذي لا ذمة له... فإن لكلِّ من الناس لأس عهدا من الله تعالى بالحفظ والكَاءة، فإذا القى بيده إلى التَّهلكة انقطع عهده"(57).

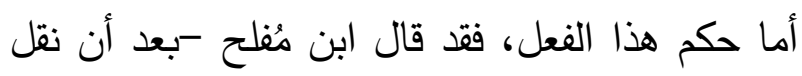
قولا عن الإمام أحمد بالكراهة-: "وسبق أن الإمام أحمد أنس رحمه الله كره النوم على سطح ليس بدحمَّر ، الألى وللأصحاب رحمهم الله خلاف في كراهته المطلقة، هل هي للتحريم أو للتزيه؟ وقد يقال: هذه الكراهة للتنزيه؛

(56) أَخْرجه أحمد (20749) من طريق هشامِ الدَّستُو ائي، و البخاري في

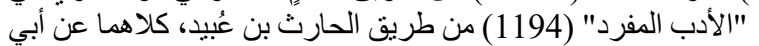

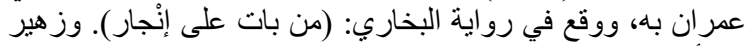

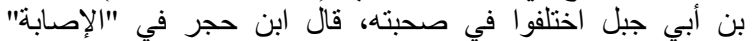

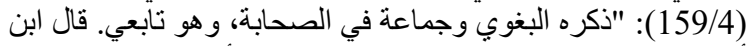

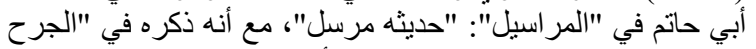
و التعديل" بين صحابيين؛ فاقتضى ذاني ذلك أنه صحابي".

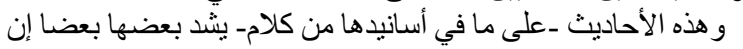
شاء الله؛ إذ ضدفها ليس شديدا. (57) الكاثف عن حقائق السنن (شرح مشكاة المصابيح) (10/ 3073) انظر: فيض القدير (51/ 91).
قال الخطًابي: "هذا الحرف يروى بنتح الحاء وكسرها، ومعناه معنى الِّتِر والحجاب، فمن قال (الحِجى)

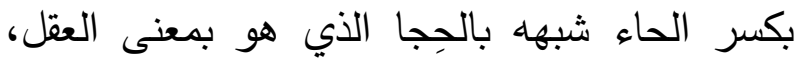

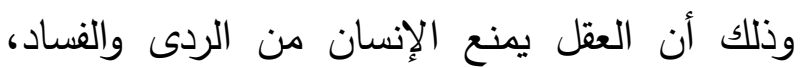

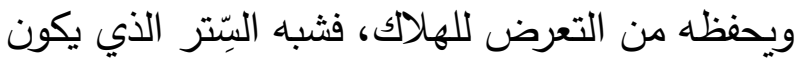

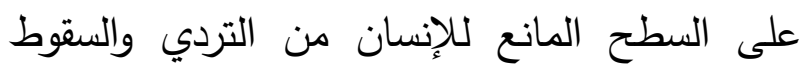
بالعقل المانع له من أفعال السوء المؤدية له إلى الردى الكى الكي

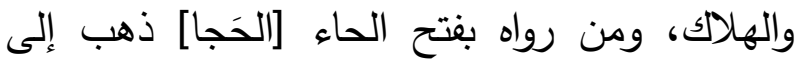

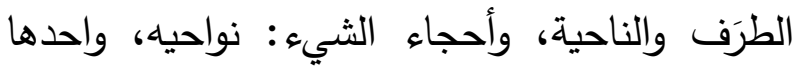
حَجًا، مقصور "(52). و(الحجار) جمع حجر بالكسر وهو الحائط، أو من الإن إنهان الحجرة وهي حجرة الدار: أي: "إنه يحجر الإنسان النائم ويمنعه عن الوقوع والسقوط" (53).

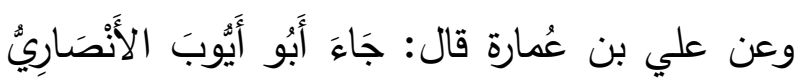

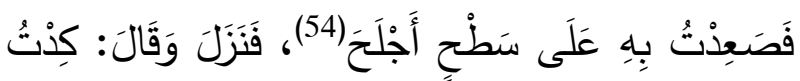

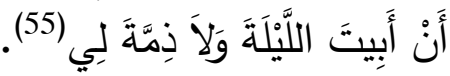

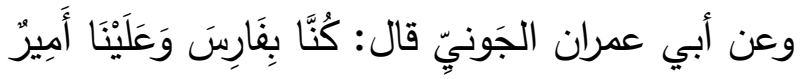

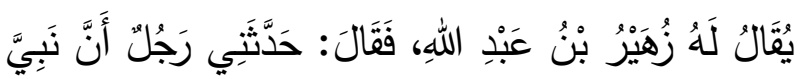
اللهِ

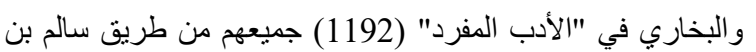

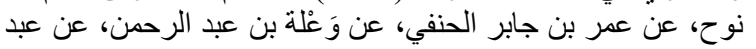

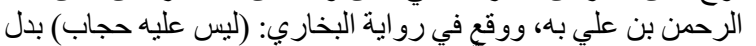

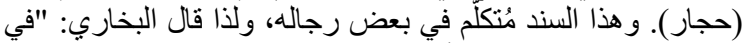

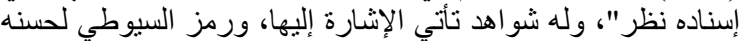

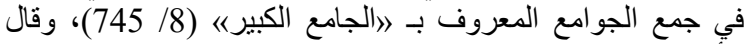
الألباني في الجامع الصغير وزيادته (326/3) (1054): صحيح.

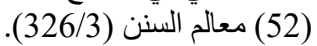

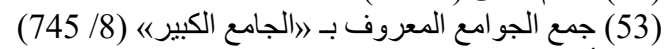
(54) أي: "ليس عليه جدار، و لا شيء يمنع من السقوط". النهاية في غريب

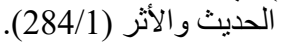

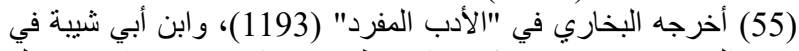

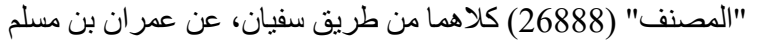


ثم قال: "يا عائششةُ، اسقينا"، فجاءت بعُسٍّ (60) مِنْ لَبَنِ

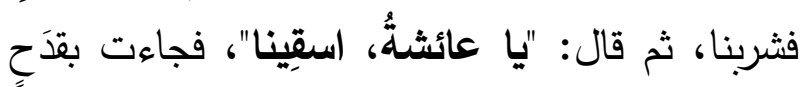
صغير فشربِنا، ثم قال: "اإن شِئتم بِتُّم وإنْ شِئتمْ

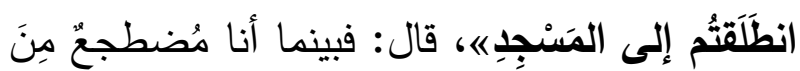
السَّحَرِ على بَطني إذا رَجُلُّ يحرِكِني برجِجِله، فقال: "اإنْ

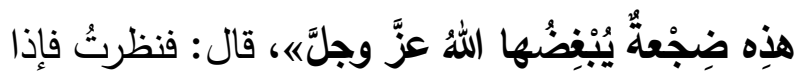

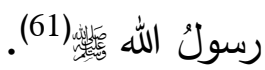

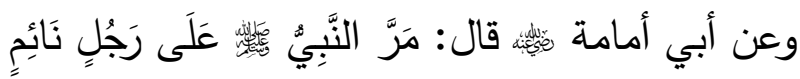
فِي الْمَسْجِدِ مُنْبَطِحِح عَلَى وَجْهِهِ، فَضَرَبَبَهُ بِرِجْلِهِ وَقَالَ:

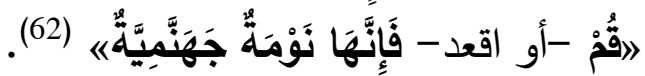

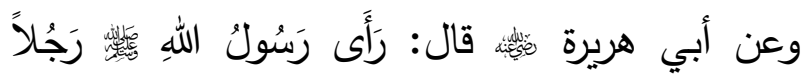

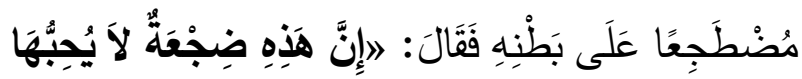
الآلَُّ (63) فهذه الأحاديث الواردة عنه لئس في النهي عن النوم على البطن ذكر أهل العلم بالثريعة والطب أن الحكمة في ذلك ما يترتب على هذه النومة من الضرر والاختلال، ولهذا نص الفقهاء وأئمة المذاهب على

إن الصحبة لعبد الله ابنه، و إنه صاحب القصة. حديثه عن يحيى بن أبى كثير ، و عليه اختلفو ا فيه".

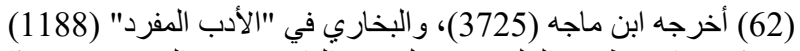

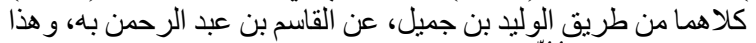

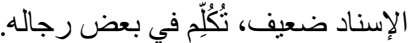

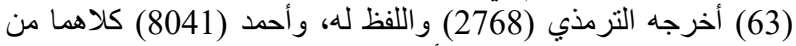

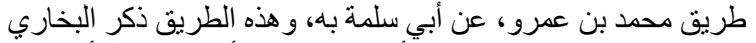

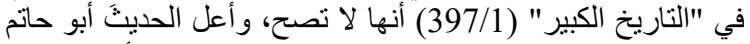

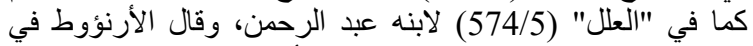

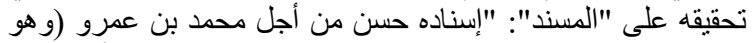

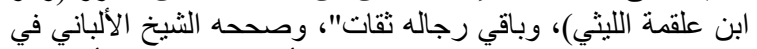

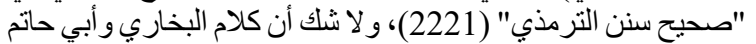

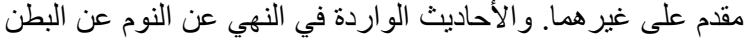
و التحذير منه لا بسلم آحادها من كلام، لكنها بمجمو عها حسنة إن شاء النطاء
لأن الغالب في هذا السلامةُ، وما غَلبت السلامةُ فيه لا يحرُم فعله، وكونَ النهي عنه للأدب واحتمال الأذى، ويتوجه قول ثالث، وهو أن ذلك يختلف باختلاف الأشخاص وعاداتهم، وصِغَر الأسطحة، ووُسعها نظرا إلى المعنى وعملا به"(58). وهذا القول الثالث قول حسن فيه نظرٌ إلى علل النصوص ومقاصدها، والله أعلم. فالحديث الشريف يلزم الإنسان الأخذ بالأسباب لسلامته، فمن بات على سطح لا حجاب عليه فقد قصر في ذلك، لأن النائم قد ينقلب في نومه وقد يقوم ولا يزال أثر النوم عليه فيسقط، فيكون هذا سبباً لهراكه. المطلب الثاني: النهي عن النوم على البطن: عن يَعيش بن طِخْفة بن قيس الغِفاري قال: كان أبي من أصحابٍ الصُّفَّة، فقال رسولُ الله لهُ

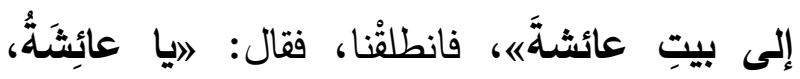
أَطعِمِينَاه، فجاءت بجَثِيشة (59) فأكلنا، ثم قال: ايايا

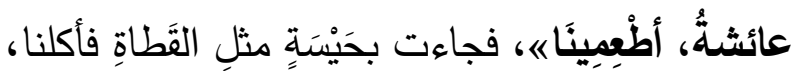

(58) الآداب الثر عية (53/3) لابن مُفلح.

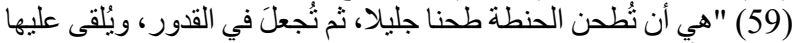

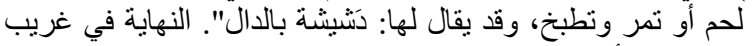

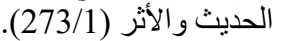

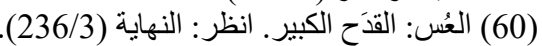

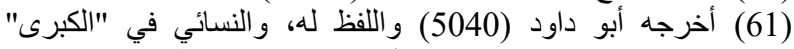

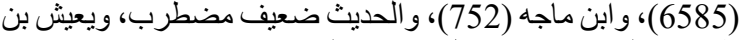
طخفة اختلفو ا فيه كثير ا، قال ابن عبد البر في "الاستيعاب" (774/2):

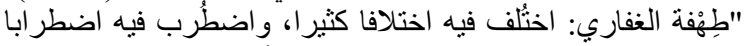

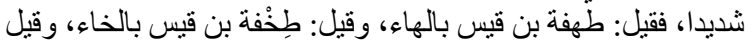

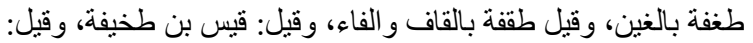

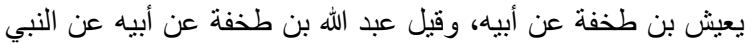

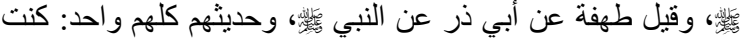

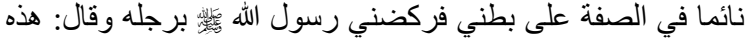
نومة يبغضها الله. وكان من أصحاب الصفة. ومن أهل أهل العلم من يقول: 


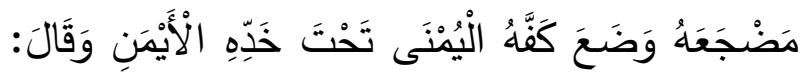

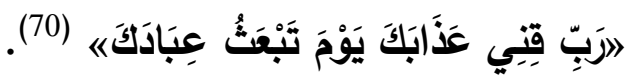

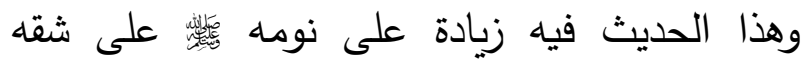
الأيمن= أنه كان يضع يده اليمنى تحت خده، فجملة

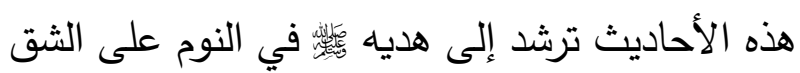

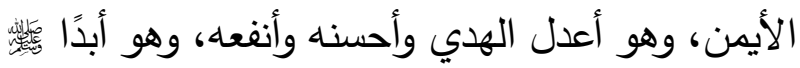
يدل أمتاه على ما ينفعهم في دينهم ودنياهم.

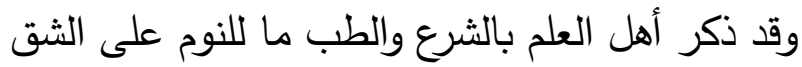
الأيمن من فوائد ومنافع، فمن ذلك: قول ابن الن الجوزي

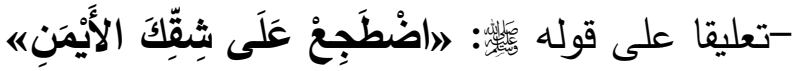

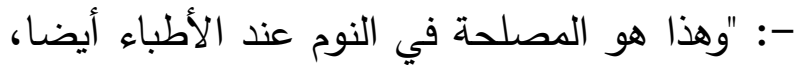
فإنهم يقولون: ينبغي أن يضطجع على الجانب الأيمن

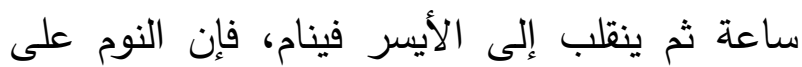
اليمين سبب انحدار الطعام؛ لأن نَصبة المعدة تقتضي الطي ذلك، والنوم على اليسار يهضم؛ لاشتمال الكبد على

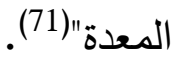
ونقله عنه ابن حجر في "الفتح"، وزاد عليه في قوله: "وخَص الأيمنَ لفوائد؛ منها: أنه أسرع إلى الانتباه، ومنها: أن القلب متعلق إلى جهة اليمين فلا يثقل

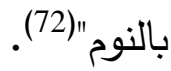
وكون النوم على الجنب الأيمن أسرعَ إلى الانتباه ذكره

(69) أخرجه البخاري (1160)؛ ومسلم (743) من غبر ذكر الثق الأيمن،

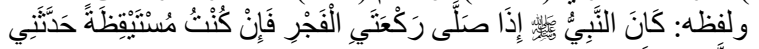

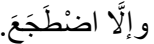

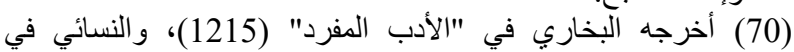

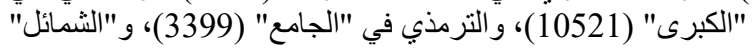
(254) من طرق، و الحديث صحيح. (71) كثف المشكل من حديث الصحيحين (110/240/2). .(110/11) (72)
قال ابن القيه: "وأردى النوم: النوم على الظهر، ولا يضر الاستلقاء عليه للراحة من غير

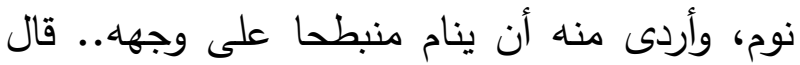

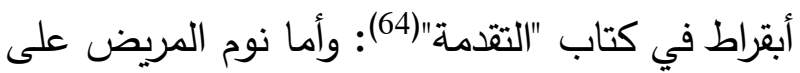

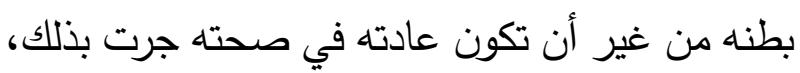
فذلك يدل على اختلاط عقل، وعلى ألم في نواحي

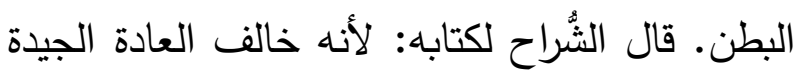
إلى هيئة رديَّة من غير سبب ظاهر ولا باطن" (65). وذكر الأطباء أن النوم على البطن يسبب ضئ ضيقا في التنفس، ويَعوق حركة الققص الصدري، ويسبب انثناء الفَّرات الرقَبية، وانضغاطَ الأحشاء البطنية (66) المطلب الثالث: النوم على الثق الأيمن:

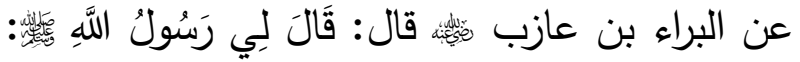

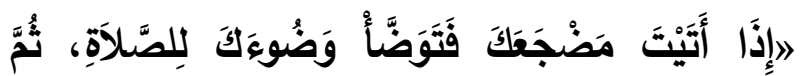

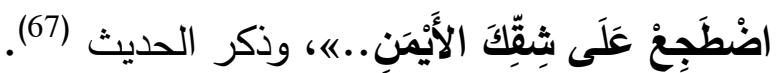

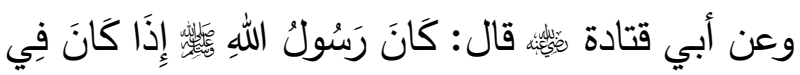

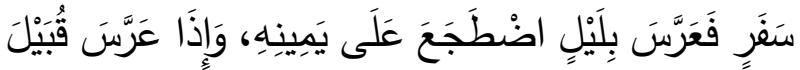

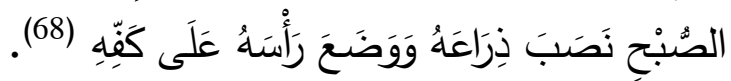

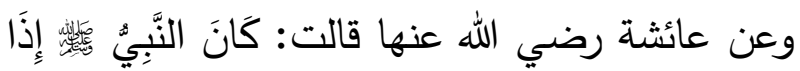

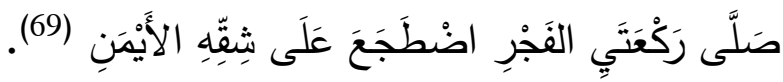

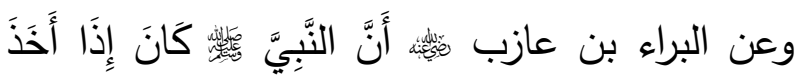

(64) أي: "تقدمة المعرفة". انظر: حاثية الموضع المُحال عليه من

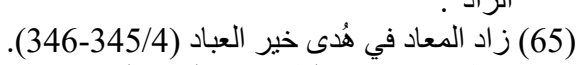

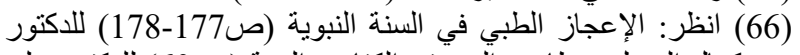

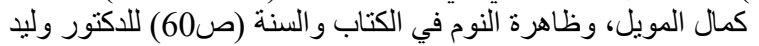


وقد يحصل للمري تقلبّ في نومه، فينقلب على بطنه من قبلُ النووي، وزاد في حكمة ذلك: أنه أو ظهره أو على جانبه الأيسر، ولا حرج في ذلك كله نهاه

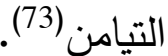

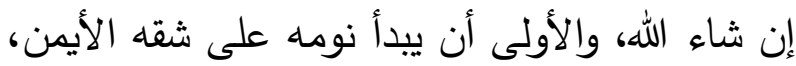
وذكر ابن القيم بعضَ ما تقدم ذكره ولخصه وزاد عليه، فإن حصل التقلب بعد ذلك من أجل الراحة فلا بأس.

المطلب الرابع: النوم مبكراً والاستيقاظ باكراً:

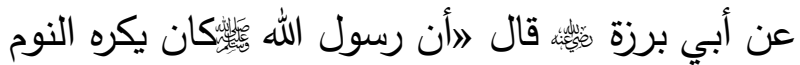
قبل العشاء والحديث بعدهاه (76)، وعن عبد الله بن برن مسعود رضي الله عنه، قال: 》جدب لنا رسول الله

السمر بعد العشاء《 (77). فقوله (جدب) أي ذمه أو عابه، وأصل السمر ضوء

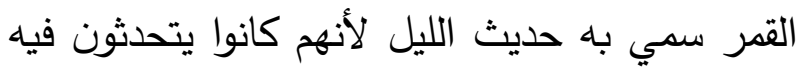

والنهي عن السمر بعد العشاء نهي كراهة لأنه يجوز السهر لطلب العلم، فقد قال البخاري في صحيحه: باب السمر في العلم (79).

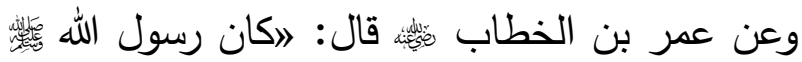
لا يزال يسمر عند أبي بكر الليلة في الأمر من أمور المسلمين وإنه سمر عنده ذات ليلة وأنا معهه (80). في المقابل حث الإسلام على الاستيقاظ باكراً لأداء

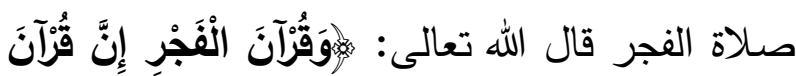

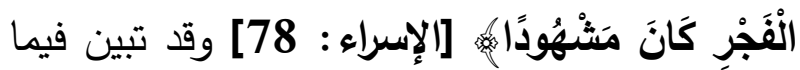
بعد علمياً الأضرار الناشئة عن السهر ليلا والفوائد

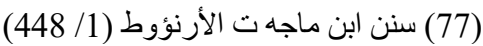

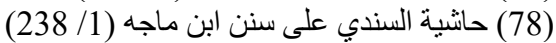

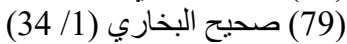
(80) صحيح ابن حبان - مخرجا (19/ (34) (379)، إسناده صحيح على فقال: "وأنفع النوم: أن ينام على الثق الأيمن؛ ليستقر

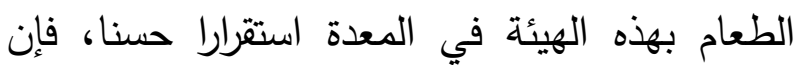
المعدة أميل إلى الجانب الأيسر قليلا، ثم يتحولَ إلى الثق الأيسر قليلا ليسرع الهضم بذلك لاشتمال المعدة الهابن

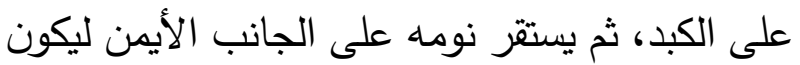

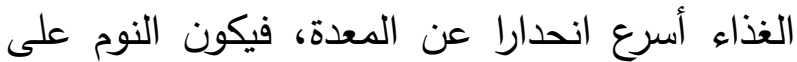

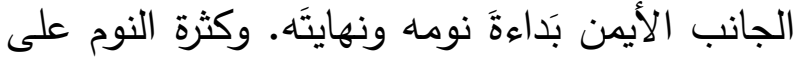
الجانب الأيسر مضر بالقلب بسبب ميل الأعضاء إليه، فتتصبُّ إليه المواد"(74). فائدة: ما ذُكر من حكمة النوم على الثق الأيمن وأنه

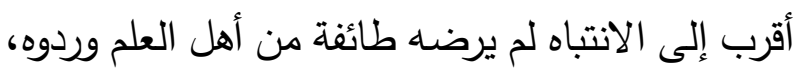

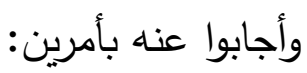

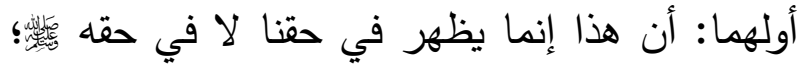
لأنه لا ينام قلبه، فلا فرق في حقه بين الثق الأيمن والأيسر . لانه لان.

ثانيهما: أن الاستغراق في النوم وعدمه مرده إلى العادة، فمن اعتاد النوم على الثق الأيمن حصل لله

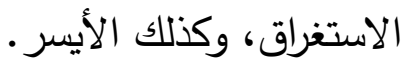
وهم يعللون اختيار الأيمن بشرفه على الأيسر ، ولتعليم أمته، والتشريع لها (75).

(73) شرح النووي على مسلم (33/17). (74) ز زاد المعاد (745/3).

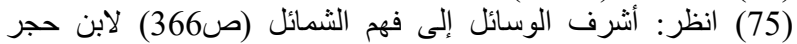

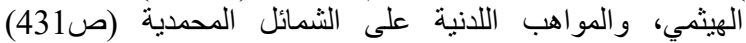

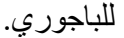


طلوع الثمس، ويقول الدكتور شابيرو :إن الذهاب إلى النوم في وقت محدد كل مساء والاستيقاظ في وقت معين كل صباح لا يحسن نشاط المرء في النهار فحسب، بل يهيئ الثخص لنوم جيد في الليلة

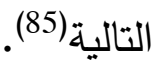

إنه الإسلام دين الفطرة التي فطر الناس عليها، فعن

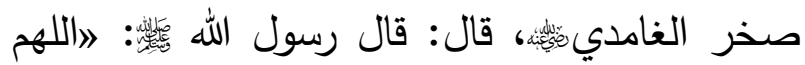
بارك لأمتي في بكورهاه (86).

المطلب الخامس: غسل اليدين بعد الاستيقاظ من لنوري

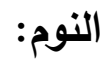

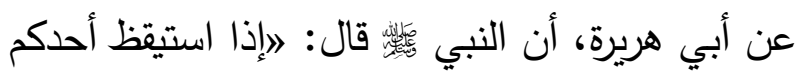
من نومه، فلا يغمس يده في الإناء حتى يغسلها ثلاثا، فإنه لا يدري أين باتت يدهي (87).

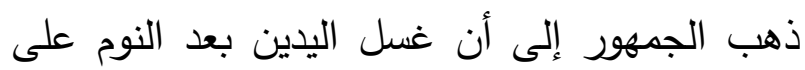
جهة الاستحباب؛ لأن يد النائم تجول في مغابنه ومواضع استجماره، وأعراقه، فقد يتعلق باليد منها

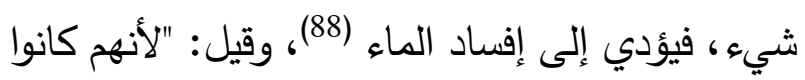
يستجمرون بالأحجار فربما نال ذلك بيده حال نومه"،

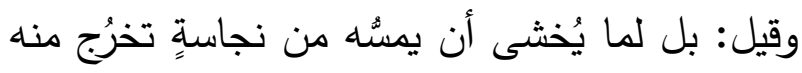
حال نومه أو غير ذلك مما يتقذَّر منه" (89).

(85) موسو عة الإعجاز العلمي في القرآن والسنة (1/ 59، بترقيم الثاملة

(86) أخرجه ابن ماجه (2/ 752) وقال السخاوي في المقاصد الحسنة

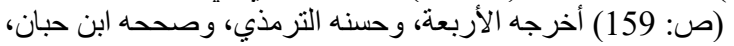

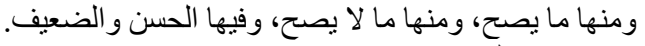

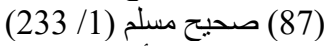
(88) المفهم لما أنشكل من تلخيص كتاب مسلم (28) (536)

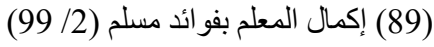

الجمة من الاستيقاظ باكراً، فقد ذكر موقع وزارة الصحة

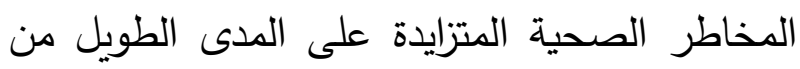
السهر هي: صعوبة في التركيز والصداع وسوء المزاج والعصبية وعدوى متكررة ونزلات البرد والأنفونزا، وزيادة الاحتمالية للإصابة بالسرطان، زيادة الكولسترول بالدم وأمراض القلب والسمنة (81. كما أن الاستيقاظ الباكر إلى صلاة الفجر يمنع النوالن المديد (82) "وهو من الثروط الصحية والجسمية والعقلية، كما أيد علم الطب وعلم النفس بأن ساعة من النصف الأول من الليل تعادل ساعتين من النصف

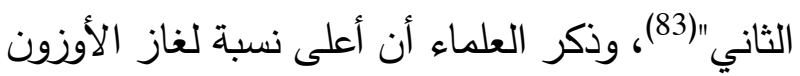

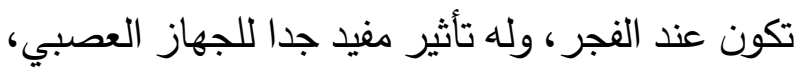
ومنشط جدا للعمل الفكري والعضلي (84). هذا الوقت هو وقت البكور وهو الساعة الأولى من الصباح والتي تسبق شروق الثمس، قال تعالى:

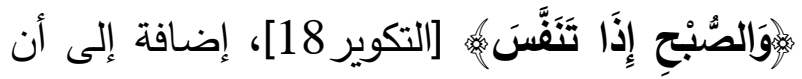
نسبة الأثعة فوق البنفجية تكون أكبر عند الثروق، وهذه الأشعة هي التي تحرض الجلد على صنع الفيتامين (د)، الذي يثبت الكلس في العظام، وضعف لهف البنية العظمية وهشاشة العظام سببها النوم إلى ما بعد

https://www.moh.gov.sa/HealthAwareness/Educatio(81) nalContent/PublicHealth/Pages/001.aspx (82) النوم المديد: هو النوم المتصل الذي يضعف نثاط الجسم إلى أدنى

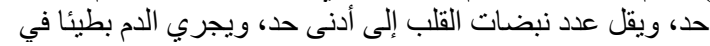

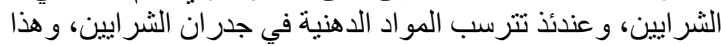

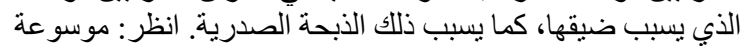

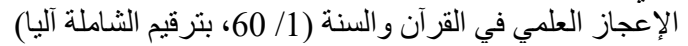

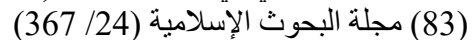
(84) موسو عة الإعجاز العلمي في القرآن والسنة (1/ 60، بترقيم الثاملة 
" فاستحب لله غسل يده قبل أن يدخلها في وضوئه البحث، وهي:

1- جاءت الأحاديث بالنهي عن ترك النار مشتعلة على معنى التنطف والتنزه" (90). عند النوم، وذلك أن النار لا يُؤمن جانبها، ولا سبيل بالنيل في كثير من الأحيان إلى إخماد لهيبها، والتجرِبة والواقع خير شاهد ودليل على هذا. 2- الثيطان يسلك كل سبيل من أجل الإضرار

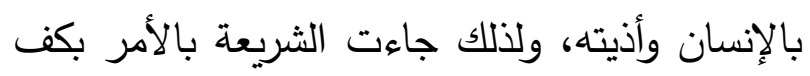
الصبيان في الليل وإغلاق الأبواب وتغطية الآنية وإيكاء القرب. 3- أهمية تعاهد المري فراشَه حين يقصده للنوم، وذلك أنه لا يدري ما فيه من المؤذيات مما قد يكون خلفه عليه. 4- السواك مستحب في كل حال، ويتأكد استحبابه عند القيام من النوم لما يحصل من تصاعد الأبخرة إلى الفم وتغير رائحته.

5- يستحب غسل اليدين قبل النوم من الدسم ورائحة اللحم، وذلك أن الذي ينام وفي يده شيء من ذلك لا لانين

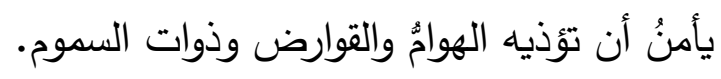
6- ضرورة الأخذ بأسباب السلامة والوقاية حال

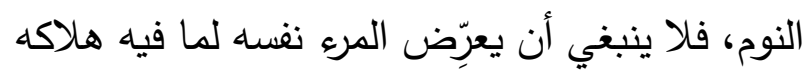

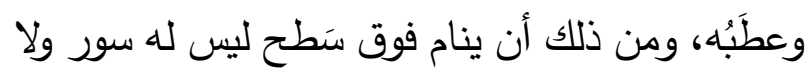

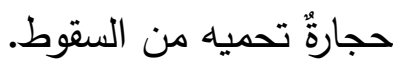

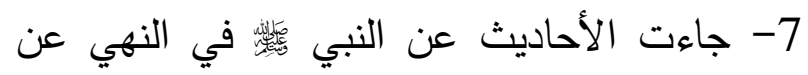
النوم على البطن، وذكر أهل العلم بالثريعة والطب النب

والحقيقة التي كثفها الطب الحديث يقول البوطي" إذا

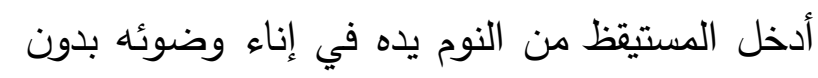
أن يغسلها ويطهرهما قبل ذلك وانتقلت الجراثيم للماء ثم اغترف منه وغسل وجهه وعينيه فربما تدخل تلك ونكان

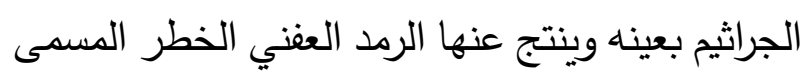
بالرمد (91)" وهذا النهي إجراء وقائي في منع اليد التي عني لتئي تتلوث بمجرد ملامستها لعضو من أعضاء الجسم أثناء النوم أو ملامستها للشرج فتسبب نقل الجراثيم أو

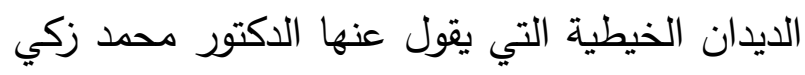

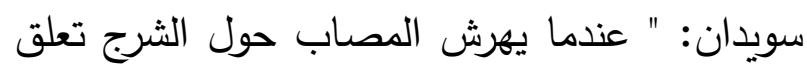
البويضات بأظافره فتدخل من جديد إلى أمعائه عند ئد تتاول الطعام، أو قد يتلوث طعام الآخرين من يديه

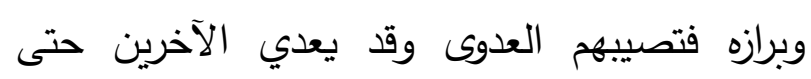
بمصافحتهم"(92). فهذه دعوة للنظافة والبعد عن أسباب الإصابة بالوباء

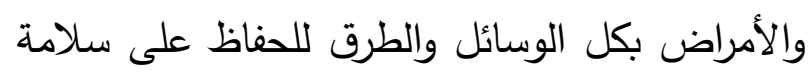
الإنسان.

\section{الخاتمة:}

الحمد الله رب العالمين، وصلى الله وسلم على نبينا محمد وآله وصحبه أجمعين، أما بعد، فهذه أهم النتائج

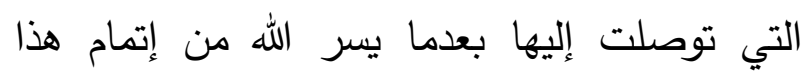

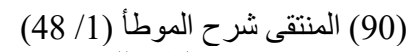
(91) معجزات في الطب للنبي محمد صلى الله عليه وسلم، محئ، محد سعيد

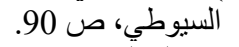
(92) مجلة البحوث الإسلامية (90) (359) 
أن الحكمة في ذلك ما يترتب على هذه النومة من طبعة وسنة نشر. o الآداب للبيهقي: أحمد بن الحسين بنره بن علي بن

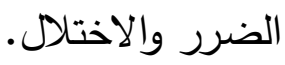

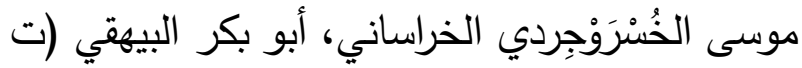

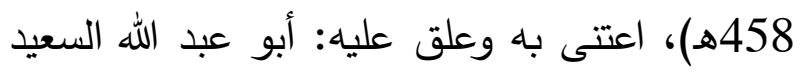
المندوه، مؤسسة الكتب الثقافية، بيروت - لبنان، ط1

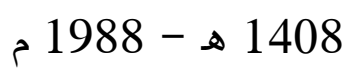
0 الأدب المفرد: أبو عبد الله محمد بن إسماعيل

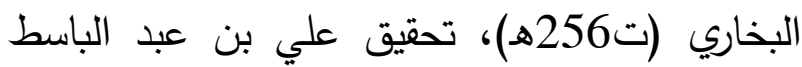
مزيد، وعلي بن عبد المقصود رضوان، مكتبة

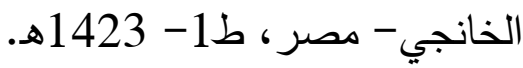
o الإعجاز الطبي في السنة النبوية: الدكتور كمال المويل، دار ابن كثير - دمشق، ط2- 1426هـ. O إكمال المعلم بفوائد مسلم: عياض بن موسى بن عياض اليحصبي السبتي، أبو الفضل (ت 544هـهـ،

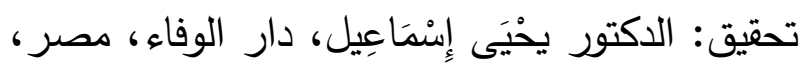
ط1- 1419 هـ - 1998 م. o التاريخ الكبير : أبو عبد الله محمد بن إسماعيل بن مأن إبراهيم البخاري الجعفي (ت256هـ)، تحقيق السيد هاشم الندوي، دار الفكر - بيروت، دون رقم طبعة

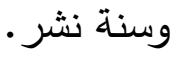

0 تحفة الأحوذي بشرح سنن الترمذي: أبو العلا محمد عبد الرحمن بن عبد الرحيم المباركفوري، دار الكتب العلمية- بيروت، ط1- 1410هـ. o التمهيد لما في الموطأ من المعاني والأسانيد: أبو عمر يوسف بن عبد الله بن محمد بن عبد البر

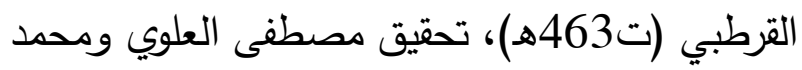

8- أرشدت الأحاديث إلى هديه الثق الأيمن، وهو أعدل الهدي وأحسنه وأنفعه.

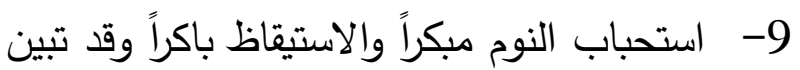
فيما بعد علمياً الأضرار الناشئة عن السهر ليلا والفوائد الجمة من الاستيقاظ باكراً. 10- غسل اليدين بعد الاستيقاظ من النوم على جهة الاستيعا.

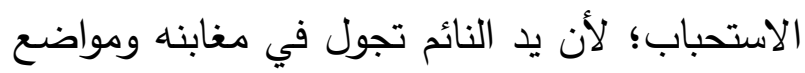
استجماره، وأعراقه، فقد يتعلق باليد منها شيء، فيؤدي إلى الإصابة بالوباء والأمراض.

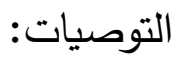
1- دراسة الأحاديث النبوية الثريفة التي تتعلق بسلامة الإنسان في كافة الجوانب ونشرها في مختلف وسائل التواصل الاجتماعي وذلك حفظاً على سلامة الناس واقتداء بسنة نبينا محمد صلى الله عليه وسلم

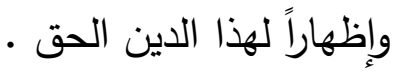

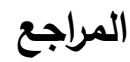

المراجع والمصادر : - إل o القرآن الكريم. 0 الإحسان بترتيب صحيح ابن حبان: علاء الدين علي بن بلَبان الفارسي (ت739هـ)، تحقيق شعيب لإنبان الأرنؤوط، مؤسسة الرسالة- بيروت، ط2- 1414هـ.

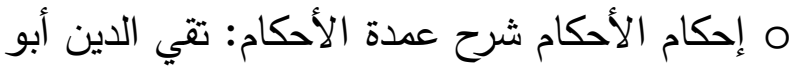
الفتح محمد بن على بن وهب القشيري (ابن دقيق العيد) (ت702هـ)، مطبعة السنة المحمدية، دون رقم 
المعراج الدولية للنشر - الرياض، ط1- 1416هـ. o زاد المعاد في هدي خير العباد: شمس الدين أبو عبد الله محمد بن أبي بكر (ابن قيم الجوزية) (ت751هـ)، تحقيق محمد أجمل الإصلاحي، دار

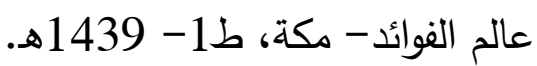
0 سنن ابن ماجه: أبو عبد الله محمد بن يزيد القَّويني (ت273هـ)، حكم على أحاديثه وآثاره وعلق عليه:

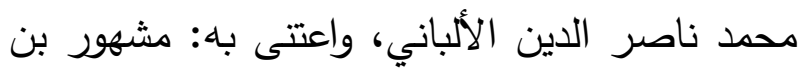
حسن سلمان، مكتبة المعارف- الرياض، ط1- دون

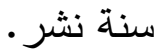
0 سنن أبي داود: أبو داود سليمان بن الأشعث السجستاني (ت275هـ)، حكم على أحاديثه وآثاره وعلق عليه محمد ناصر الدين الألباني، واعتنى به مشهور بن حسن سلمان، مكتبة المعارف- الرياض،

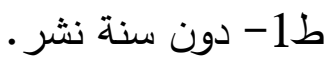
o السنن الكبرى: أبو عبد الرحمن أحمد بن شعيب النسائي (ت303هـ)، حققه حسن عبد المنعم شلبي، مؤسسة الرسالة- بيروت، ط1- 1421هـ. 0 سنن النسائي: أبو عبد الرحمن أحمد بن شعيب النسائي (ت303هـ)، حكم على أحاديثه وآثاره وعلق بنق عليه محمد ناصر الدين الألباني، واعتنى به مشهور بن حسن سلمان، مكتبة المعارف- الرياض، ط1-

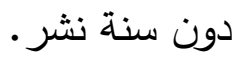
0 شرح الإلمام بأحاديث الأحكام: تقي الدين أبو الفتح محمد بن على بن وهب القشيري (ابن دقيق العيد) (ت702هـ)، حققه وعلق عليه محمد خلوف العبد الله،
البكري، وزارة الأوقاف والثئون الإسلامية- الدغرب،

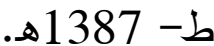
o التوضيح لشرح الجامع الصحيح: سراج الدين أبو حفص عمر بن علي الأنصاري (ابن الملقّن) (ت804هـ)، تحقيق دار الفلاح للبحث العلدي بإشراف خالد الرَّبَّاطووجمعة فتحي، دار النوادر - دمشق، ضمن إصدارات الأوقاف القطرية، ط1- 1429هـ. 0 جامع الترمذي: أبو عيسى محمد بن عيسى بن سورة الترمذي (ت279ه)، حكم على أحاديثه وآثاره وعلق عليه محمد ناصر الدين الألباني، واعتنى به مشهور بن حسن سلمان، مكتبة المعارف- الرياض، ط1- دون سنة نشر. o الجامع المسند الصحيح المختصر من أمور رسول الله وسننه وأيامه: أبو عبد الله محمد بن إسماعيل

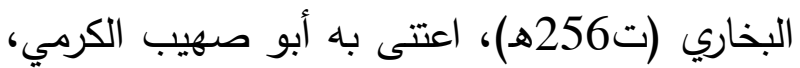

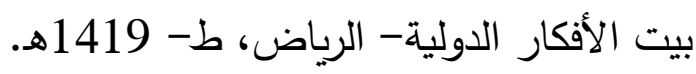
0 جمع الجوامع المعروف بـ 》الجامع الكبير《: جلال الدين السيوطي (ت 911 هـ)، تحقيق: مختار إبراهيم الهائج - عبد الحميد محمد ندا - حسن عيسى عبد الظاهر ، الأزهر الشريف، القاهرة - جمهورية مصر العربية ، ط2 1426 هـ - 2005 م الارهن 0 حاشية السندي على سنن ابن ماجه: محمد بن عبد

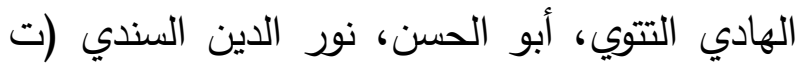
1138هـ)، دار الجيل - بيروت. 0 ذخيرة العقبى في شرح المجتبى (شرح سنن النسائي): محمد بن علي بن آدم الإثيوبي الولَّوي، دار 
0 ظاهرة النوم في القرآن والسنة: الدكتور وليد بن محمد الحمد، دون رقم طبعه ودار نشر • 0 فتح الباري شرح صحيح البخاري: شهاب الدين أبو الفضل أحمد بن علي بن حجر العسقلاني (ت 911ه)، صححه وأشرف على طبعه محب الدين الخطيب، دار المعرفة- بيروت، ط-1379هـ. 0 فيض القدير شرح الجامع الصغير: زين الدين محمد المدعو بعبد الرؤوف بن علي بن زين العابدين الحدادي ثم المناوي القاهري (ت 1031هـ)، المكتبة

التجارية الكبرى - مصر ط1 1356هـ 0 كشف المشكل من حديث الصحيحين: أبو الفرج عبد الرحمن بن محمد بن علي (ابن الجوزي) (ت597هـ)، تحقيق علي حسين البوَّاب، دار الوطنالرياض، ط1 - 1418هـ. 0 الكوكب الوهَّاج والروض البهَّاج في شرح صحيح مسلم بن الحجاج: محمد الأمين الهرري الثافعي، دار المنهاج- جدة، ط1- 1430 هـ. 0 لسان العرب: جمال الدين أبو الفضل محمد بن مكرم بن منظور المصري (ت 711هـ)، دار صادر بيروت، ط3- 1414هـ. 0 مجلة البحوث الإسلامية - مجلة دورية تصدر عن الرئاسة العامة لإدارات البحوث العلمية والإقتاء والدعوة والإرشاد: الرئاسة العامة لإدارات البحوث العلمية والإفتاء والدعوة والإرشاد. 0 مجمع الزوائد ومنبع الفوائد: نور الدين أبو الحسن علي بن أبي بكر بن سليمان الهيثمي (ت807هـ)،
دار النوادر - دمشق، ط2- 1430هـ. 0 شرح الطيبي على مشكاة المصابيح (الكاشف عن حقائق السنن): شرف الدين الحسين بن عبد الله بن محمد الطيبي (ت743هـ)، تحقيق عبد الحميد هنداوي، مكتبة نزار مصطفى الباز - مكة المكرمة،

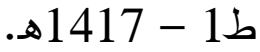
0 شرح النووي على مسلم: أبو زكريا محي الدين يحيى بن شرف النووي (ت676هـ)، دار إحياء التراث العربي- بيروت، ط2- 1392هـ. 0 شرح سنن أبي داود: شهاب الدين أبو العباس أحمد بن حسين بن علي بن رسلان الرملي الثافعي (ت 844هـ)، تحقيق عدد من الباحثين بدار الفلاح بإشراف خالد الرباط، دار الفلاح للبحث العلمي وتحقيق التراث- الفيوم، ط1- 1437هـ. o الشمائل المحمدية: أبو عيسى محمد بن عيسى بن سورة الترمذي (ت279هـ)، تحقيق عبده علي كوشك، مكتبة نظام يعقوبي الخاصة- البحرين، ط51433هـ. 0 صحيح ابن حبان بترتيب ابن بلبان: محمد بن حبان بن أحمد بن حبان بن معاذ بن مَعْبَ، التميمي، أبو حاتم، الدارمي، البُستي (ت 354هـ)، تحقيق شعيب الأرنؤوط، مؤسسة الرسالة - بيروت، ط2•1993 - 1414 0 صحيح الجامع الصغير وزياداته: أبو عبد الرحمن محمد ناصر الدين، بن الحاج نوح بن نجاتي بن آدم، الأشقودري الألباني (ت 1420هـ)، المكتب الإسلامي 
o المقاصد الحسنة في بيان كثير من الأحاديث

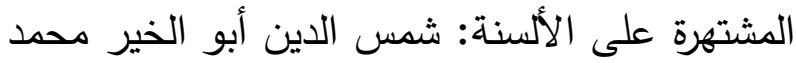
بن عبد الرحمن بن محمد السخاوي (ت 902هـ)، تحقيق محمد عثمان الخشت، دار الكتاب العربي بيروت، ط1- 1405 هـ - 1985م. 0 مقاييس اللغة: أبو الحسين أحمد بن فارس (ت395هـ)، تحقيق شهاب الدين أبو عمرو، دار الفكر - بيروت، ط2- 1418هـ. o المنتقى شرح الموطأ: أبو الوليد سليمان بن خلف بن سعد بن أيوب بن وارث التجيبي القرطبي الباجي الأندلسي (ت 474هـ)، مطبعة السعادة - محافظة

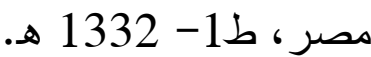
0 المواهب اللدنية على الثمائل المحمدية: إبراهيم بن محمد الباجوري (ت1277هـ)، دار المنهاج- جدة، ط 1436-5 -5 - 5

0 موسوعة الإعجاز العلمي في القرآن والسنة: محمد راتب النابلسي، دار المكتبي - سورية - دمشق، ط21426 هـ - 2005 م. o النهاية في غريب الحديث والأثر: مجد الدين أبو السعادات المبارك بن محمد الجزري (ابن الأثير) (ت606هـ)، تحقيق محمود الطناحي وطاهر الزاوي، دار إحياء الكتب العربية- القاهرة، دون رقم طبعة

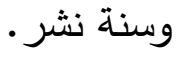
o https://www.moh.gov.sa/HealthAwarenes s/EducationalContent/PublicHealth/Pages/001. aspx
تحقيق حسام الدين القدسي، مكتبة القدسي- القاهرة،

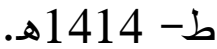
0 مسند الإمام أحمد بن حنبل (ت 241هـ): تحقيق شعيب الأرناؤوط وآخرون، مؤسسة الرسالة- بيروت، ط-20- 1420هـ

O المسند الصحيح المختصر من السنن بنقل العدل عن العدل عن رسول الله: أبو الحسين مسلم بن الحجاج القشيري النيسابوري (ت261هـ)، اعتنى به

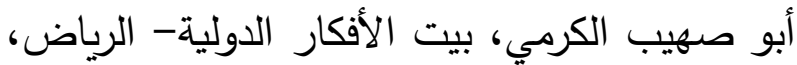
ط- 1419هـ. - ماه. 0 معالم السنن: أبو سليمان محمد بن محمد الخطابي البستي (ت388هـ)، تحقيق سعد بن نجدت عمر ، مؤسسة الرسالة- بيروت، ط- 1439هـ. 0 معزات في الطب للنبي محمد صلى الله عليه وسلم، محمد سعيد البوطي، ط1 o المعجم الكبير: أبو القاسم سليمان بن أحمد الطبراني (ت360هـ)، تحقيق حمدي عبد المجيد السلفي، مكتبة ابن تيمية- القاهرة، ط2- دون سنة نشر 0 معرفة الصحابة: أبو نعيم أحمد بن عبد الله الأصبهاني (ت430هـ)، تحقيق عادل العزازي، دار الوطن - الرياض، ط1- 1419هـ. O المفهر لما أشكل من تلخيص كتاب مسلم: أبو العباس أحمد بن عمر بن إبراهيم القرطبي (ت656هـ)، تحقيق مجموعة من الباحثين، دار ابن كثير - دمثق، ط1- 1417هـ. 


\title{
The care of the Prophet's Sunnah about human safety: the Prophet's sayings of a person in sleep are a model
}

\author{
Dr. Masoud bin Mohammed Al-Qahtani \\ Assistant Professor of the Quran and Sunnah \\ malqahtany@kau.edu.sa \\ Department of Sharia and Islamic Studies \\ Faculty of Arts and Humanities. \\ King Abdulaziz University / Jeddah \\ 1442 AH corresponding to 2020 AD
}

\begin{abstract}
Praise to God and peace be upon Prophet Muhammad, his family, and all his companions. This research includes tow areas that shows the care of the Prophet's Sunnah about the safety of a person in sleep. Results shows encouragement of washing hands before and after sleep, encouragement of falling asleep early, encouragement of waking up early, and warning of leaving the fire burning when sleeping. Recommendations: study the prophetic's sayings that discuss the safety of a person in sleep and share them in social media to ensure the safety of people according to the Sunnah of our Prophet Muhammad, peace be upon him, and to show this true religion.

Lord of the Worlds

Dr. Masoud bin Mohammed Al-Qahtani

Assistant Professor of the Quran and Sunnah
\end{abstract}

